\title{
Project Plan for Full Scale Smoke Movement and Smoke Control Tests
}

John H. Klote

U.S. DEPARTMENT OF COMMERCE

National Bureau of Standards

National Engineering Laboratory

Center for Fire Research

Gaithersburg, MD 20899

June 1988

Sponsored by:

American Society of Heating, Refrigerating, and Air-Conditioning Engineers, Inc.

Atlanta, GA 30329

Bell Atlantic Telephone Company

Arlington, VA 22201

New Jersey Bell Telephone Company

Newark, NJ 07101

U.S. Fire Administration

Emmitsburg, MD 21727

U.S. Veterans Administration

Washington, DC 20420

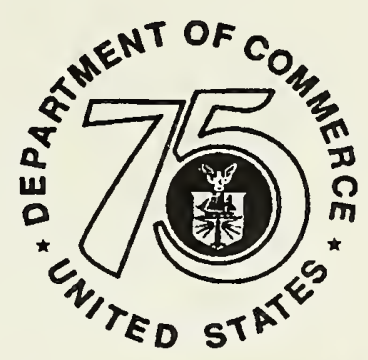

76 Yeen Silmulating America's Progress 1913-1008

US West Incorporated

Denver, CO 80202 



\section{PROJECT PLAN FOR FULL SCALE SMOKE MOVEMENT AND SMOKE CONTROL} TESTS

John H. Klote

U.S. DEPARTMENT OF COMMERCE

National Bureau of Standards

National Engineering Laboratory

Center for Fire Research

Gaithersburg, MD 20899

June 1988

Sponsored by:

American Society of Heating, Refrigerating, and

Air-Conditioning Engineers, Inc.

Atlanta, GA 30329

Bell Atlantic Telephone Company

Arlington, VA 22201

New Jersey Bell Telephone Company

Newark, NJ 07101

U.S. Fire Administration

Emmitsburg, MD 21727

U.S. Veterans Administration

Washington, DC 20420

US West Incorporated

Denver, CO 80202

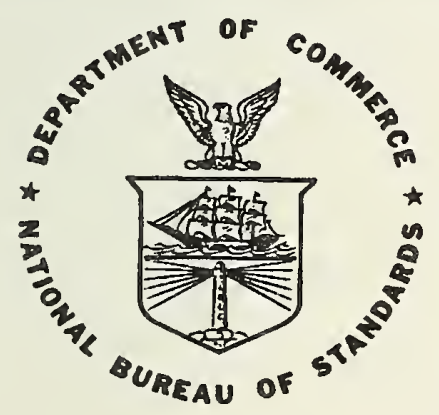

U.S. DEPARTMENT OF COMMERCE, C. William Verity, Secretary NATIONAL BUREAU OF STANDARDS, Ernest Ambler, Director 
TABLE OF CONTENTS

LIST OF FIGURES . . . . . . . . . . . . . . . . . . . . . . . . . . . . iv

LIST OF TABLES . . . . . . . . . . . . . . . . . . . . . . . . . . v v

Abstract . . . . . . . . . . . . . . . . . . . . . . . . 1

1. INTRODUCTION . . . . . . . . . . . . . . . . . . . . . . . 1

2. TEST BUILDING . . . . . . . . . . . . . . . . . . . . . . . 2

3. MODIFY TEST BUILDING . . . . . . . . . . . . . . . . . . . . . . 3

4. SMOKE CONTROL SYSTEMS . . . . . . . . . . . . . . . . . . . . . . . 4

4.1 Smoke Control System Types... . . . . . . . . . . . . . . . 4

4.2 Computer Analysis . . . . . . . . . . . . . . . . . . . . . . 6

4.3 Description of Fan Systems . . . . . . . . . . . . . . . . . 9

5. CALibrate building LEAKAgE . . . . . . . . . . . . . . . . . . . 10

5.1 Floors and Exterior Walls . . . . . . . . . . . . . . . 10

5.2 Shaft Walls and Doors . . . . . . . . . . . . . . 12

5.3 Fan Requirements . . . . . . . . . . . . . . . . 12

6. INSTRUMENTATION . . . . . . . . . . . . . . . . . . . . . . . . . 13

7. TEST SERIES . . . . . . . . . . . . . . . . . . . . . . . . . . 14

8. SUMMARY . . . . . . . . . . . . . . . . . . . . . . . 16

9. REFERENCES . . . . . . . . . . . . . . . . . . . . . . . . 17

APPENDIX A COMPUTER OUTPUT FOR PLAZA HOTEL BUILDING

SMOKE CONTROL SYSTEM ANALYSIS . . . . . . . . 29 


\section{LIST OF FIGURES}

Figure 1. Plaza Hotel building basement floor plan . . . . . . . . . . . 18

Figure 2. Plaza Hotel building first floor plan . . . . . . . . . . . . 19

Figure 3. Plaza Hotel building second floor plan . . . . . . . . . . . . 20

Figure 4. Plaza Hotel building third floor plan . . . . . . . . . . . . 21

Figure 5. Plaza Hotel building typical floor plan

for floors four through seven . . . . . . . . . . . . . . . . 22

Figure 6. Conceptual smoke control systems with the smoke zone being the fire floor . . . . . . . . . . . . 23

Figure 7. Conceptual smoke control systems with the smoke zone being the fire floor and the floor above . . . . . 24

Figure 8. Effective flow network for estimating magnitude of pressurization needed during calibration . . . . . . . . . 25

Figure 9. Conceptual instrumentation configuration for smoke control tests . . . . . . . . . . . 26

Figure 10. Conceptual instrumentation configuration for smoke movement tests . . . . . . . . . . . . 27

Figure 11. Schematic piping arrangement for gas analysis equipment . . . . . . . . . . . . . . . . . . . . 28 


\section{LIST OF TABLES}

Table 1. Flow areas $\left(f t^{2}\right)$ used for computer analysis . . . . . . . . . . 7

Table 2. Conditions for the computer runs . . . . . . . . . . . . . . . 7

Table 3. Computer calculated pressure differences (in $\mathrm{H}_{2} \mathrm{O}$ )

for the first smoke control approach . . . . . . . . . . . 8

Table 4. Fan Requirements . . . . . . . . . . . . . . . . . . 10

Table 5. Estimated flows (cfm) to calibrate second floor exterior

leakage at various pressure differences. . . . . . . . . . 13

Table 6. Test series description . . . . . . . . . . . . . . . . 15 

PROJECT PLAN FOR FULL SGALE

SMOKE MOVEMENT AND SMOKE CONTROL TESTS

John H. Klote

\section{Abstract}

This report presents a project plan to test combinations of zoned smoke control and stairwell pressurization systems under real fire conditions to evaluate the appropriateness of current design methods of analysis for these systems. The report describes the test building, smoke control systems, calibration of building leakage areas, test instrumentation, and test series. As the project progresses much will be learned from the initial stages of work, and the need for some adjustments in the test series or other parts of the project plan may become apparent.

Key words: air movement, fire tests, pressurization, smoke control, stairwells.

\section{INTRODUCTION}

There have been no major fires in buildings with engineered smoke control systems. With the exception of simple pressurized stairwells, no engineered smoke control system has been tested under fire conditions. Some new systems have been tested with non-fire generated smoke (chemical smoke from smoke bombs), however such tests are not conclusive because the resulting smoke is cold. This project will test combinations of zoned smoke control and stairwell pressurization systems under real fire conditions to determine if the pressures recommended in the ASHRAE Smoke Control Manual (Klote and Fothergill 1983) can prevent smoke infiltration at the boundaries of smoke control systems. Smoke movement with and without smoke control will be studied.

The project will be conducted in the Plaza Hotel building in Washington DC. The work in this building will have a duration of three months, and this work will consist of the following tasks: 
- Modify test building

- Install smoke control systems

- Calibrate building leakage

- Install instrumentation

- Conduct tests

These tasks are described in this report. It should be noted that there are some differences between this project plan and the general description of the project in the research proposal. These differences are due to the characteristics of the test building and due to a desire to make the most of the project. These differences in no way reduce the level of effort of the project or the total number of tests, and the differences are all described in this report. It is anticipated that the Center for Fire Research will take charge of the test Plaza Hotel building in late summer, and that the tests will be conducted in the fall of 1988 .

This report is a plan for the project, and as the project progresses much will be learned from the initial stages of work. Based on this information, the need for some adjustments in the test series or other parts of the project plan may become apparent.

\section{TEST BUILDING}

The Plaza Hotel buildirg is a masonry structure consisting of two wings, one three stories and the other seven stories tall. The two wings were built at different times, and it appears that the building was constructed some time around the turn of the century. The wings are connected at only one location on each floor as can be seen from the floor plans of figures 1 through 5 . The building has no central forced air HVAC system, but is heated by steam water radiators and cooled by window air conditioners. Thus dedicated smoke control systems will be designed and installed as described later.

The connections between the wings at each floor will be sealed off, and the tests will be conducted in the seven story wing, using the shorter wing as 
an instrumentation area. The second floor will be the fire floor and the fires will be conducted in a room and in the corridor near the stairwell as indicated by the fire hardening shown on figure 3 .

The building is being used by the Capitol Police for office space and will be available for our tests when construction of their new office space is finished. The Plaza Hotel building is scheduled for demolition after the fire tests are conducted. The building is located near the U.S. Capitol Building in Washington DC. The Architect of the Capitol has obtained official approval of the U.S. Senate Committee on Rules and Administration for NBS to use the Plaza Hotel Building for this fire research project. The stipulations of this approval are:

- All activities of the project will be coordinated with the Office of the Architect of the Capitol.

- The project will not interfere with the normal functions of the Senate.

Further the Office of the Architect of the Capitol has agreed to coordinate communications and requests for service with the many local fire departments in the area.

\section{MODIFY TEST BUILDING}

The modifications of the test building consist of:

- Sealing the connection between the wings on each floor

- Caulking windows

- Patching various holes in walls, floors and partitions

- Fire hardening the burn room with calcium silicate board

- Fire hardening parts of the corridor with calcium silicate board

Figures 1 through 5 indicate locations of the connections to be sealed. The sealing of the connections between the wings is done so that the four 
story wing can be used for instrumentation and data collection in an environment protected from the fire and smoke of the tests. The windows are old with wood frames and appear to be very leaky. The windows will be caulked in an attempt to get the overall building leakage closer to the range that would be expected for a modern building. This expected range of leakage is discussed later in this paper. The areas to be fire hardened are shown on figure 3, further second floor windows will be fire hardened.

\section{SHOKE CONTROL SYSTEMS}

\subsection{Smoke Control System Types}

In the zoned smoke control concept, a building is divided into a number of smoke control zones, each zone separated from the others by partitions, floors, and doors that can be closed to inhibit the movement of smoke. In the event of a fire, pressure differences produced by mechanical fans are used to. limit the smoke spread to the zone in which the fire initiated. The concentration of smoke in this smoke zone goes unchecked and accordingly, in zoned smoke control systems, it is intended that building occupants evacuate the smoke zone as soon as possible after fire detection. The concepts of stairwell pressurization and zoned smoke control are discussed in detail in the ASHRAE Smoke Control Manual and in the Recommended Practice for Smoke Control Systems (NFPA 92A 1988).

The test facility will be fitted with two smoke control systems: a zoned smoke control system and a pressurized stairwell. The following three smoke control systems will be tested:

1. zoned smoke control with the fire floor (second floor) as the smoke control zone plus stairwell pressurization,

2. zoned smoke control with the fire floor and the floor above as the smoke control zone plus stairwell pressurization (see figure 7 ), 
3. zoned smoke control with the fire floor as the smoke control zone and without stairwell pressurization.

For all these systems, pressurization air is supplied from the outside, and exhaust air goes to the outside. The locations of the fans for zoned smoke control are shown on figures 2, 3, 4 and 5 . The location of the stairwell pressurization fan will be outside the building at grade level. System 1 is illustrated conceptually in figure 6 , and it will not use the exhaust fan on the 3rd floor or the supply fan on the 4 th floor. System 2 is illustrated conceptually in figure 7, and it will not use the supply fan on the third floor. System 3 is the same as system 1, except the stair pressurization fan will not be operating. The fans that are not used for a test will be sealed over to prevent leakage through them during that test.

A fourth system consisting of smoke control system 2 without stairwell pressurization can be arranged, but this system is not included in the test plan. The research proposal discussed tests of elevator pressurization systems, these are not included because the elevator shaft in the Plaza Hotel Building does not lend itself to elevator shaft pressurization. Such elevator systems were recently the subject of a series of full scale fire tests in Canada (Tamura and Klote 1987). With the limited number of tests possible in the Plaza Hotel, it is believed that work should be concentrated on zoned smoke control with and without stairwell pressurization.

The supply and exhaust rates of the zoned smoke control systems will be based on six air changes per hour, which amounts to about $1880 \mathrm{cfm}$ per floor. Six air changes was selected as this is about the upper limit of the air flow capacity that can be expected from an HVAC system. It is well known that pressure fluctuations in pressurized stairwells can be a significant problem when stairwell doors are opened and closed. There are many design approaches for dealing with this fluctuation problem as discussed in the ASHRAE Smoke Control Manual. The stairwell pressurization system used for this test series will use the Canadian approach of having an exterior stairwell door open throughout pressurization to reduce the adverse effects of doors opening and 
closing. Based on experience, the stairwell will be pressurized by a fan delivering up to $9000 \mathrm{cfm}$ of supply air.

\subsection{Computer Analysis}

Because there will be a pressurized stairwell and a zoned smoke control system in the test building, the performance of each system will be affected by the operation of the other. The performance of the first smoke control approach was analyzed using the computer program ASCOS (Klote 1982). For the ASCOS program, a building is represented by a network of spaces or nodes, each at a specific pressure and temperature. The stairwells and other shafts are modeled by a vertical series of spaces, one for each floor. Air flows through leakage paths from regions of higher pressure to regions of lower pressure. These leakage paths are open doorways, gaps around closed doors, open windows, and cracks around closed windows. Leakage also occurs through construction cracks in partitions, floors, exterior wall and roofs. Supply air can be introduced into a shaft or other building space to simulate a pressurization system, and exhaust air can be removed from any space. The input for ASCOS consists of the network description, areas of leakage paths, outside temperature, inside temperature, pressurization and exhaust air flow rates. The program output consists of the steady flows through the network and the corresponding pressures.

The analysis included two conditions of building leakage, which are loose and average tightness. The two leakage conditions were studied to obtain an idea of system performance because the actual leakage areas are not known. However, it is believed that the actual flow areas will be found to be in the range between the values selected for loose and average tightness. The flow areas used for this analysis were based on experience and on the typical leakages listed in appendix $C$ of the ASHRAE Smoke Control Manual. These flow rates are listed in table 1 .

The computer analysis was conducted for temperatures of $70^{\circ} \mathrm{F}$ indoors and $40^{\circ} \mathrm{F}$ outdoors. This outside temperature is felt to be appropriate in that the smoke control systems will probably not encounter lower outside 
Table 1. Flow areas $\left(f t^{2}\right)$ used for computer analysis

Area Located Between

Building and outside at basement

Building and outside at 1 st floor

Building and outside at floors

2 through 7

Floors

Stairwell and building per floor with stairwell doors closed

Stairwell and building per floor with stairwell doors opened

Stairwell and outside at floors

1 through 7
Stairwell and outside at basement

Elevator shaft and building per floor

Elevator and outside at penthouse (Vent)
Loose

0.10

3.00

0.81

0.22

0.29

10.5

0.10

10.5

1.07

5.00
Average

0.10

1.50

0.41

0.11

0.24

10.5

0.05

10.5

0.77

5.00

Table 2. Conditions for the computer runs

Run

1

2

3

4

5
Description of Conditions

Loose building leakage listed in table 1. All stairwell doors closed except the exterior stairwell door

Average building leakage listed in table 1. All stairwell doors closed except the exterior stairwell door

Loose building leakage listed in table 1 . All stairwell doors open except the second floor door.

Average building leakage listed in table 1. All stairwell doors open except the second floor door.

Loose building leakage listed in table 1 except for the flow area between the elevator shaft and the building which is $0.20 \mathrm{ft}^{2}$. All stairwell doors open except the second floor door. 
Table 3. Computer calculated pressure differences (in $\mathrm{H}_{2} \mathrm{O}$ )

for the first smoke control approach

$\begin{array}{llllll}\text { Location } & \text { Run 1 } & \text { Run 2 } & \text { Run 3 } & \text { Run 4 } & \text { Run 5 } \\ \text { Stairwell to 2nd floor } & 0.153 & 0.274 & 0.102 & 0.233 & 0.208 \\ \text { lst floor to 2nd floor } & 0.100 & 0.260 & 0.101 & 0.233 & 0.206 \\ \text { 3rd floor to 2nd floor } & 0.151 & 0.366 & 0.104 & 0.236 & 0.211 \\ \text { Elevator shaft to 2nd } & & & & & \\ \text { floor } & 0.046 & 0.150 & 0.068 & 0.176 & 0.107\end{array}$

Note: The second floor is the smoke zone, and the first and second floors are pressurized.

temperatures for daytime tests in the fall season in Washington DC. (Design of a system for a normal building would have to consider both summer and winter design temperatures as discussed in the ASHRAE Smoke Control Manual.) A description of the building conditions for the computer runs is listed in table 2 , and a summary of the computer generated data from these computer runs is listed in table 3. Computer output is listed in appendix A for both leakage conditions and for two conditions of open stairwell doors.

For a smoke control system in an unsprinklered building, NFPA 92A suggests a minimum design pressure difference of 0.10 in $\mathrm{H}_{2} \mathrm{O}$ at the boundaries of the smoke control system for a ceiling height of 9 feet. The floor to ceiling height in the Plaza Hotel is 8 feet 7 inches. For purposes of these tests, meeting the NFPA suggested level of pressurization will be considered acceptable performance.

The computer analysis was conducted for all interior stairwell doors closed and for all interior stairwell doors open except on the fire floor. It is apparent from table 3 , that the system performance is acceptable for the boundaries of the second floor (smoke zone) to the stairwell, the first floor, and the second floor. For the loose leakage condition (runs 1 and 3 ), the 
pressure differences to the elevator shaft are not sufficient, if the second floor elevator shaft walls are considered boundaries of the smoke control zone. The definition of a smoke control boundary is not well established. The supply and exhaust rates could be increased to increase the pressure difference to the elevator shaft. However, increasing these flow rates would mean that supply and exhaust would be more than six air changes, which many people feel is the upper limit for zoned smoke control systems. Another possibility would be a lower leakage area between the building and the elevator. To evaluate this possibility, run 3 was conducted over again except the flow area between the elevator and building was reduced to $0.20 \mathrm{ft}^{2}$. This run is listed as run 5, and, the pressure difference in question was 0.107 in $\mathrm{H}_{2} \mathrm{O}$ which is an acceptable value. Thus the performance of the first smoke control approach can be considered acceptable provided that the leakage of the elevator shaft can be modified in extreme cases. A limited number of computer runs (not shown here) for the other smoke control approaches were conducted, and the performance of these approaches is comparable to that of the first approach.

\subsection{Description of Fan Systems}

For zoned smoke control, the fans will have variable volumetric flow capability with a maximum capacity of $2000 \mathrm{cfm}$ and will be located on the $1 \mathrm{st}$, 2nd, 3rd and 4th floors (figures $1-5$ ). The fans will be connected by duct through window openings to the outside. The static pressure across these fans will equal the losses in the ducting plus the pressure difference between outside and the floor where the fan is located. The duct systems have not been designed, but the duct diameter probably will be 16 in with a pressure loss of about 0.1 in $\mathrm{H}_{2} \mathrm{O}$ per 100 feet at maximum capacity. Allowing for losses at fittings, inlets, outlets and the flow measuring equipment, the loss of the duct system should not exceed 1.25 in $\mathrm{H}_{2} \mathrm{O}$. From appendix $\mathrm{A}$ run 4 , the maximum pressure difference to be expected from the building to the outside is on the second floor and is about 0.25 in $\mathrm{H}_{2} \mathrm{O}$. Thus the fans for zoned smoke control should be capable of meeting $2000 \mathrm{cfm}$ at 1.5 in $\mathrm{H}_{2} \mathrm{O}$. For these motors, electrical power can be supplied by 240 Volts AC wiring that currently supplies window air conditioning units. 
The fans used for zoned smoke control will also be used to calibrate the building leakage areas as discussed later, and the minimum capacities of these fans is also discussed later. Table 4 lists the requirements of fans.

Table 4. Fan Requirements

$\begin{array}{llllll}\text { Fan } & \text { Smoke Control Use } & \begin{array}{c}\text { Temperature } \\ \text { Rating } \\ \left({ }^{\circ} \mathrm{F}\right)\end{array} & \begin{array}{l}\text { Minimum } \\ \text { Capacity } \\ (\mathrm{cfm})\end{array} & \begin{array}{l}\text { Maximum } \\ \text { Capacity } \\ \text { (cfm) }\end{array} & \begin{array}{l}\text { Static** } \\ \text { Pressure } \\ \left.\text { (in } \mathrm{H}_{2} \mathrm{O}\right)\end{array} \\ 1^{*} & \text { 1st floor pressurization } & \text { none } & 600 & 2000 & 1.50 \\ 2^{*} & \text { 2nd floor exhaust } & 600 & 600 & 2000 & 1.50 \\ 3^{*} & \text { 3rd floor exhaust } & \text { none } & 600 & 2000 & 1.50 \\ 4^{*} & \text { 3rd floor pressurization none } & 330 & 2000 & 1.50 \\ 5^{*} & \text { 4th floor pressurization none } & 330 & 2000 & 1.50 \\ 6^{*} & \text { Stairwell pressurization none } & 5000 & 9000 & 1.40 \\ \\ \end{array}$

\section{CALIBRATE BUILDING LEAKAGE}

In order to evaluate the performance of the smoke control system and to allow computer simulation of test results, the leakage paths throughout the building need to be evaluated. A comprehensive series of tests will be conducted to calibrate the leakage areas between floors, in exterior walls, in stairwell walls, and in elevator shaft walls.

\subsection{Floors and Exterior Walls}

Fans 1 through 5 (table 4) will be used for calibration of leakage areas of exterior walls and floors. The technique used is illustrated by the example of evaluating the leakage area in the exterior walls of the third floor and of the leakage area in the third floor. All leakage paths to the 
stairwe11, elevator shaft and other shafts are sealed. The 2nd, 3 rd and 4 th floors are pressurized, and the supply flow rates are adjusted so that pressure differences to the floors above and below are zero. Within the limits of accuracy of this test, all of the air supplied to the third floor flows through the exterior walls. The mass flow rate, $\dot{m}$, of air to the third floor and the pressure difference, $\Delta \mathrm{P}_{\mathrm{B} \text { Оз }}$, from the building to the outside are measured. The leakage area, $\mathrm{A}_{\mathrm{BO}_{3}}$, between the building and the outside at the third floor is calculated as

$$
\mathrm{A}_{\mathrm{BO3}}=\frac{\dot{\mathrm{m}}}{\mathrm{C}_{\mathrm{BO3}}\left(2 \rho \Delta \mathrm{P}_{\mathrm{BO3}}\right)^{\frac{1}{2}}}
$$

The value of the flow coefficient, $\mathrm{C}_{\mathrm{B} 0_{3}}$, can be estimated based on experience, and the density, $\rho$, of air in the third floor space is calculated from the perfect gas law. Then the fan on the second floor is shut off, and the supply rates of the other fans are adjusted so that the pressure difference to the fourth floor is zero. The mass flow rate, $\dot{m}$, of air to the third floor; the pressure difference, $\Delta P_{F_{3}}$, from the third floor to the second floor; and the pressure difference, $\Delta \mathrm{P}_{\mathrm{BO}}$, from the building to the outside are measured. Within the limits of accuracy of this test, all of the air supplied to the third floor flows through the exterior walls and through the third floor leakage paths. This can be expressed as

$$
\dot{\mathrm{m}}=\mathrm{C}_{\mathrm{BO3}} \mathrm{A}_{\mathrm{BO3}} \sqrt{2 \rho \Delta \mathrm{P}_{\mathrm{BO3}}}+\mathrm{C}_{\mathrm{F3}} \mathrm{A}_{\mathrm{F3}} \sqrt{2 \rho \Delta \mathrm{P}_{\mathrm{F3}}}
$$

The flow coefficients and density are evaluated as before, and the flow area, $A_{F_{3}}$, can be obtained form the above equation. The above example evaluates the flow areas by measurements at one set of flow conditions. If possible, several measurements will be conducted and the flow areas will be evaluated statistically. Further, several measurements could give an indication of the applicability of the constant flow coefficient assumption. 


\subsection{Shaft Walls and Doors}

Direct measurement of the gap thickness around a door does not lead to an accurate estimate of the flow area through the gaps because of the complex nature of these flow paths. To overcome this limitation, the leakage of the shaft walls and doors will be evaluated by the following technique. Any large areas between the shaft and the outside will be closed over and sealed, and all doors will be closed. The shaft will be pressurized, and using the method described above the total leakage area of the shaft wall plus the flow area of the gaps around doors will be determined. Then the gaps will be sealed, and the shaft will be pressurized. This will establish a leakage area for the shaft walls. The flow area of gaps around all the doors will be obtained by subtracting the first area from the second. The gaps around each door will be measured, and the resulting geometric area of the gaps will be used to proportion the total flow area of the gaps among the doors.

\subsection{Fan Requirements}

Fans 1 through 5 (table 4) will be used for leakage calibration, and the calibration process will require a large range of flow rates. The effective area concept (section 2.6 ASHRAE Smoke Control Manual) can be used to estimate the flows needed for building calibration. The effective areas for the calibration process of determining the flow area from the building to the outside at the second floor were calculated, and the resulting flow network is illustrated in figure 8 . Using the flow equation $\left(\dot{m}=\mathrm{CA}(2 \rho \Delta \mathrm{P})^{\frac{3}{2}}\right)$, the flow rate of pressurization air to the first, second and third floors for calibration can be estimated for any particular pressure difference. Table 5 lists calibration flows for both leakage conditions considered (table 1), and the flows range from 330 to $3600 \mathrm{cfm}$. The flows above $2000 \mathrm{cfm}$ can be achieved by use of two fans, and fans must be capable of delivering a minimum flow of $330 \mathrm{cfm}$. 
Table 5. Estimated flows (cfm) to calibrate second floor exterior leakage at various pressure differences

Pressure

Loose Leakage Conditions Average Leakage Conditions Difference

Floor

(in $\mathrm{H}_{2} \mathrm{O}$ )

0.10

0.20

0.10

0.20

Pressurized

1

2

3
2600

670

850
3600

950

1200
1100

330

420
1800

470

600

\section{INSTRUIENTATION}

Conceptual instrumentation layouts for tests with and without smoke control are shown in figures 9 and 10. Instrumentation will consist of thermocouples, gas analysis $\left(\mathrm{O}_{2}, \mathrm{CO}_{2}\right.$ and $\left.\mathrm{CO}\right)$, differential pressure transducers, smoke meters, a load cell, and a gas burner. The thermocouple trees consist of five type $K$ thermocouples located at intervals from the floor to the ceiling, except for the fire floor where each tree will consist of six thermocouples. About one hundred thermocouples will be made using approximately two miles of thermocouple wire. The piping arrangement for the gas analyzers is illustrated in figure 11. Smoke meters measure smoke obscuration. The load cell is used to measure the weight loss from the solid fuel fires.

Video cameras (not shown in figures 9 and 10) will be located on the floors and in the stairwell. Further, a number of telltale sprinklers will be installed on the fire floor, these will indicate the time at which real sprinklers would be activated. Instruments and video cameras on the fire floor and in the stairwell will be protected from heat damage. 
Wires from the instruments and video cameras will be run to the instrument area on the first floor of the four story wing of the building (figure 2). In this area there will be a microcomputer, channel scanner, and digital voltmeter for data acquisition. Video recording, processing, and viewing equipment will be located in the instrument area. Further, the continuous gas analyzers will be located in this area.

\section{TEST SERIES}

The test series consists of 24 tests with chemical smoke, solid fuel fires, and gas burner fires. The chemical smoke will be produced by commercial smoke bombs. It is planned that the solid fuel fires will be a standard fire consisting primarily of polyethylene beads ${ }^{1}$ that CFR is developing for the U.S. Navy. This fire will be extensively studied and characterized, and is expected to be highly repeatable. This fire will be set and allowed to go to burn-out. It will be used to study the interaction of fire and the smoke control system with all the doors and windows in the barriers of the smoke zone closed. The majority of the fires will be gas burner fires because they are simple and lend themselves to analysis. The solid fuel fires and gas burner fires will be in the range of $1 \mathrm{MW}$. A low energy fire $(200 \mathrm{KW})$ and a smoldering fire were included in the proposal for this project. But, these fires are not included in this plan, because a high energy fire is the most severe test of a smoke control system, and because of the limited number of tests possible in this project.

The fires will be unsprinklered because the long drying out time between sprinklered tests is prohibitive for a project of limited testing time. The final test could be sprinklered without causing a drying problem, and such a final sprinklered test was included in the research proposal. However, it is currently felt that more can be learned about smoke control system operation by another use of the final test.

${ }^{1}$ This is called a solid fuel fire because polyethylene is solid at room temperature. However, polyethylene beads melt before ignition and the resulting fire is similar to a liquid pool fire. 
Table 6. Test series description

Test Fire Smoke Control Stairwell Doors on Floors ${ }^{4}$ Burn Room

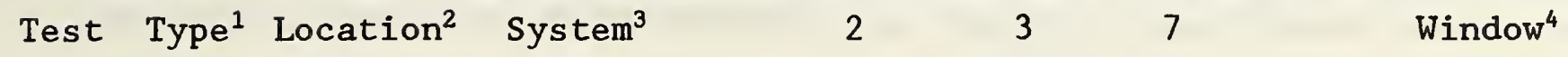

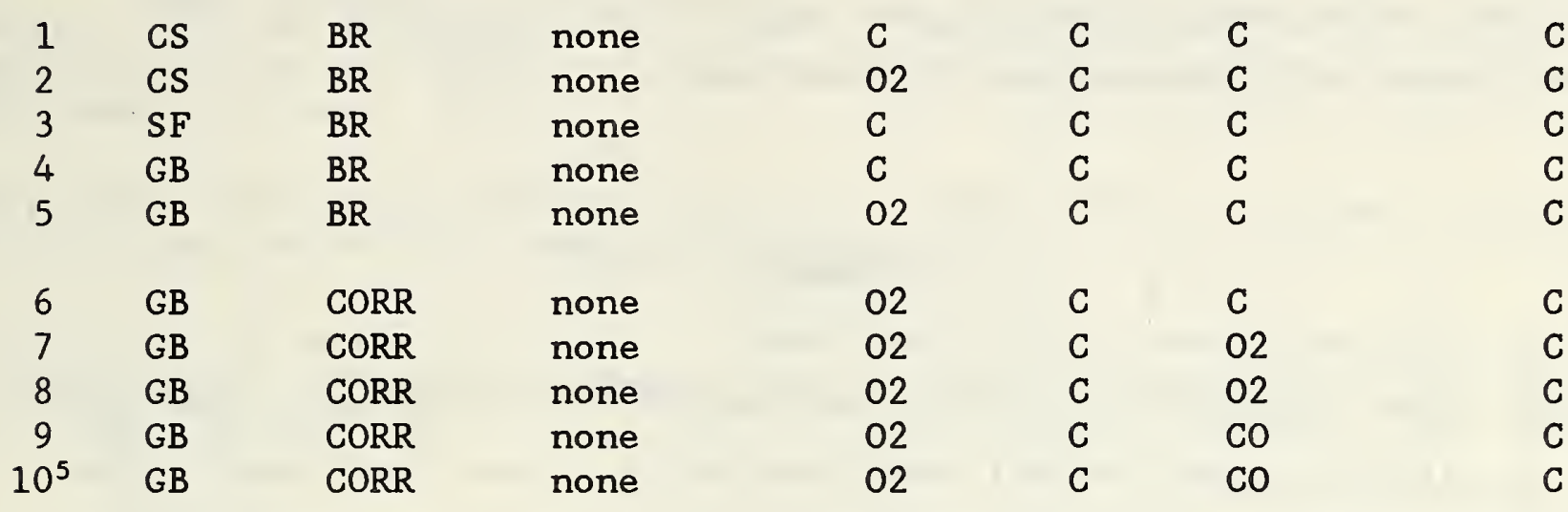

$\begin{array}{llllllll}11 & \text { CS } & \text { BR } & 1 & \text { C } & \text { C } & \text { C } & \text { C } \\ 12 & \text { CS } & \text { BR } & 1 & \text { O2 } & \text { C } & \text { C } & \text { C } \\ 13 & \text { SF } & \text { BR } & 1 & C & C & C & C \\ 14^{5} & \text { SF } & \text { BR } & 1 & C & C & C & C \\ 15 & \text { GB } & \text { BR } & 1 & C & C & C & C\end{array}$

$\begin{array}{llllllll}16 & \text { GB } & \text { BR } & 1 & \text { O2 } & \text { C } & \text { C } & \text { C } \\ 17 & \text { GB } & \text { CORR } & 1 & \text { O2 } & \text { C } & \text { C } & \text { C } \\ 18 & \text { GB } & \text { CORR } & 1 & \text { O2 } & \text { C } & \text { O2 } & \text { C } \\ 19 & \text { GB } & \text { BR } & 1 & \text { C } & \text { C } & \text { C } & \text { CO } \\ 20 & \text { GB } & \text { CORR } & 1 & \text { O2 } & \text { CO } & \text { C } & \text { C }\end{array}$

$\begin{array}{llllllll}21 & \text { GB } & \text { BR } & 2 & \text { C } & \text { C } & \text { C } & \text { O } \\ 22 & \text { GB } & \text { CORR } & 2 & \text { O2 } & \text { CO } & \text { C } & \text { C } \\ 23 & \text { GB } & \text { BR } & 3 & \text { C } & \text { C } & \text { C } & \text { C } \\ 24 & \text { GB } & \text { CORR } & 3 & \text { O2 } & \text { C } & \text { C } & \text { C }\end{array}$

1 CS is for chemical smoke test, SF is for solid fuel fire test, and GB is for gas burner fire test. These test types are described in the text.

2 BR is for burn room on second floor, and CORR is for corridor near stairwell door on the second floor. These areas are fire hardened as illustrated in figure 3 .

3 Smoke control systems 1,2 , and 3 are described in the section entitled 'smoke control system types.'

$4 \mathrm{C}$ is for closed, 02 is for opened two inches in width, and $\mathrm{CO}$ is for completely opened.

5 Repeat of earlier test to help establish a level of repeatability for the test series. 
Tests 1 through 10 study smoke movement without smoke control. These tests should provide information about smoke flow in stairwells and will act as a baseline for the smoke control tests. Tests 11 through 24 are tests of the smoke control systems previously discussed. The tests will be conducted under various conditions of opened and closed doors and windows as listed in Table 6. Two repeat tests (table 6) are included in the series to help establish a level of repeatability for the tests.

\section{SUMAARY}

Three smoke control systems will be simulated in the tests. The first approach is with the smoke control zone consisting of the fire floor. The second is with the smoke control zone consisting of the fire floor and the floor above. Both of these approaches include a pressurized stairwell, and approach three is the same as the first except without stairwell pressurization. These systems were analyzed with the ASCOS computer program, and their performance was acceptable for the range of leakage conditions anticipated in this project plan.

Zoned smoke control will be accomplished by the use of fans located on the floors to be pressurized or exhausted. These same fans will serve double duty in that they will also be used for calibration of the leakage areas of the floors, exterior walls and the elevator shaft. The stairwell pressurization fan will be used for calibration of stairwell leakage. The calibration technique is described in detail in this project plan. The fan capabilities needed depend on both smoke control use and calibration use as discussed. 


\section{REFERENCES}

Klote, J. H., 1982. A Computer Program for Analysis of Smoke Control Systems, Nat. Bur. Stand. (U. S.), NBSIR 82-2512.

Klote, J.H. and Fothergill, J.W., 1983. Design of Smoke Control Systems for Buildings, American Society of Heating, Refrigerating and Air-Conditioning Engineers, Atlanta, GA.

NFPA 92A, 1988. Recommended Practice for Smoke Control Systems, National Fire Protection Association, Batterymarch Park, MA.

Tamura, G. T. and Klote, J. H., Experimental Fire Tower Studies on Elevator Pressurization Systems for Smoke Control, ASHRAE Transactions, Vol. 93, Part II, 1987, pp 2235-2257. 


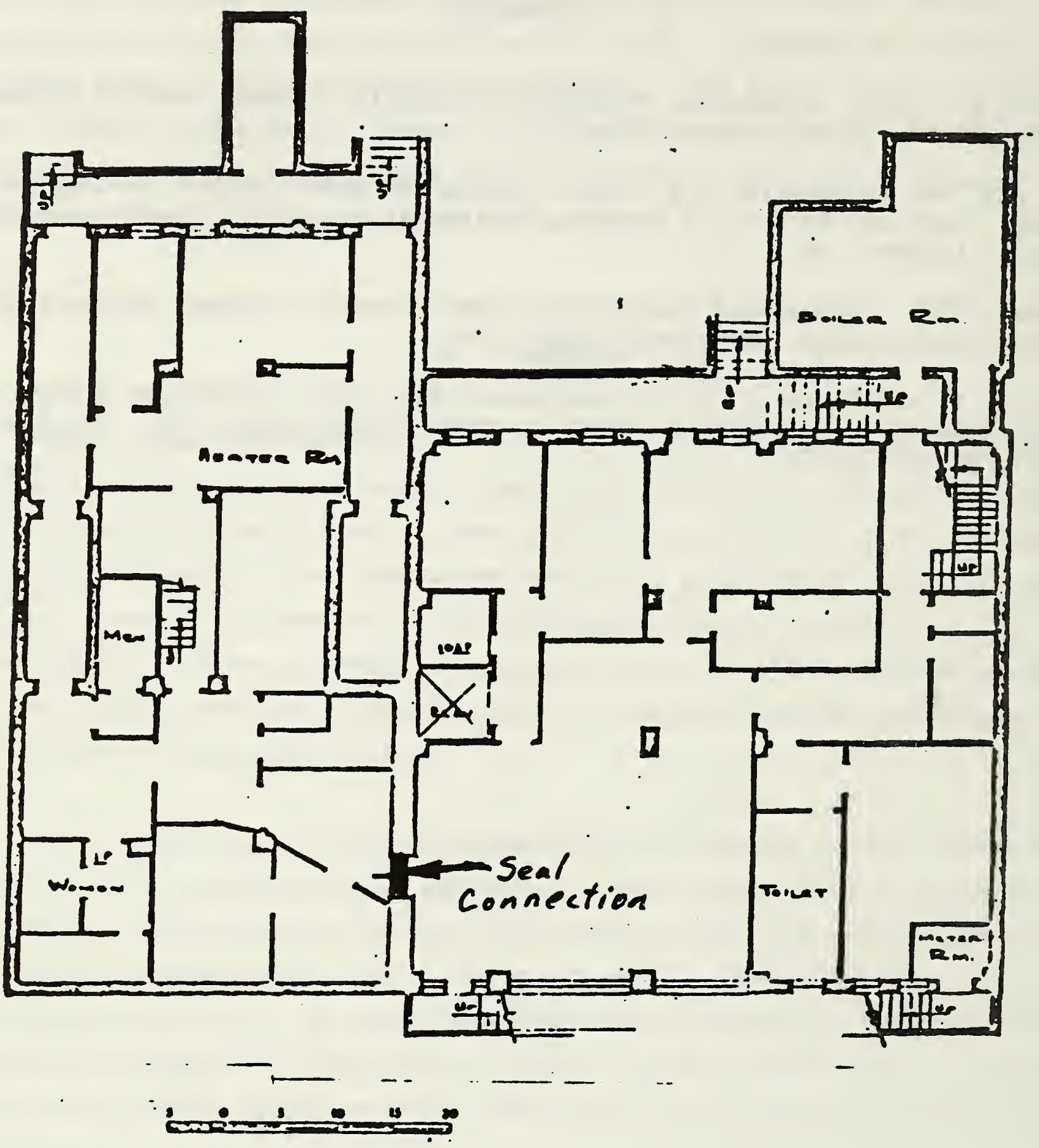

Figure 1. Plaza Hotel building basement floor plan 


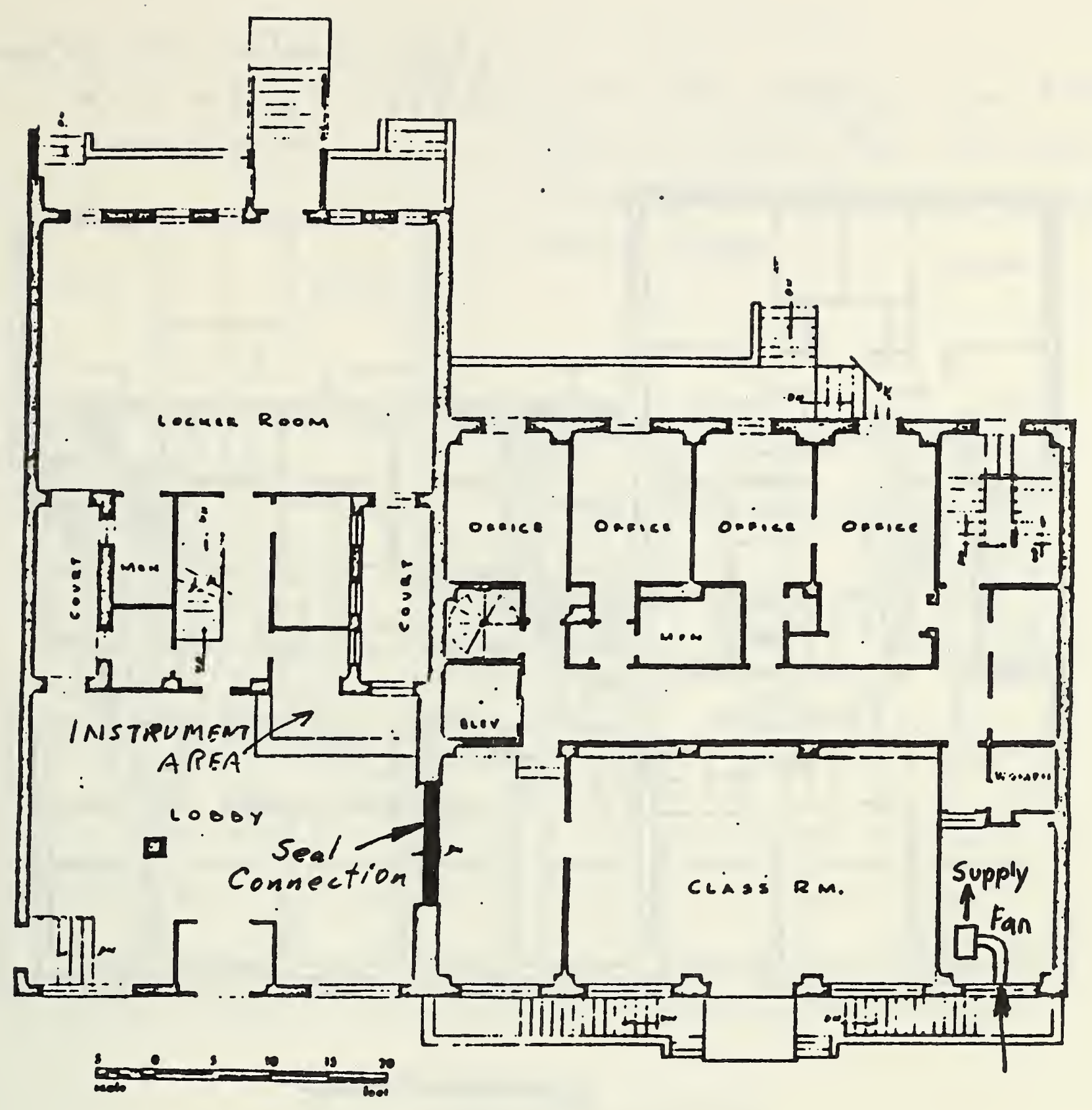

Figure 2. Plaza Hotel building first floor plan 


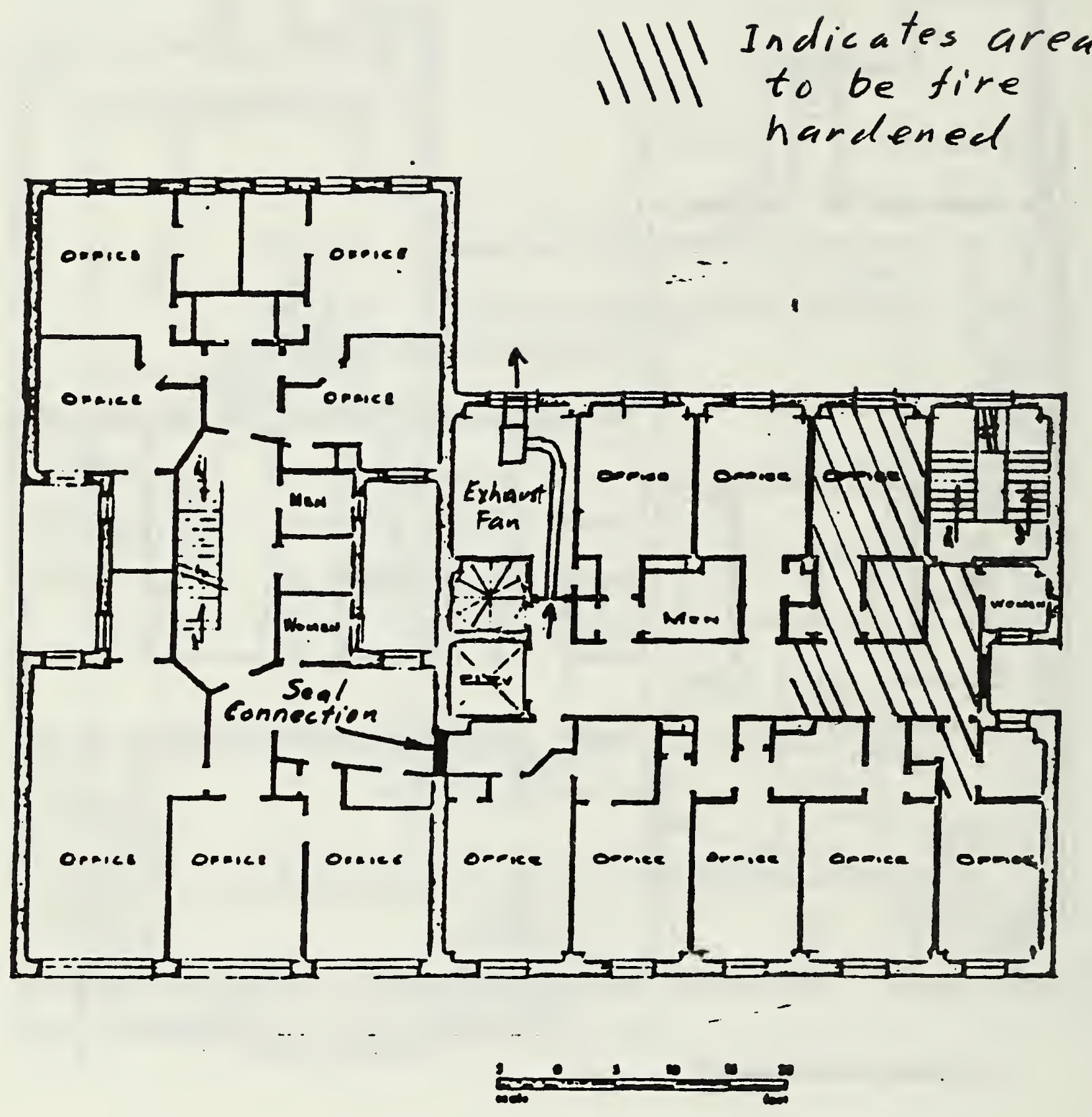

Figure 3. Plaza Hotel building second floor plan 


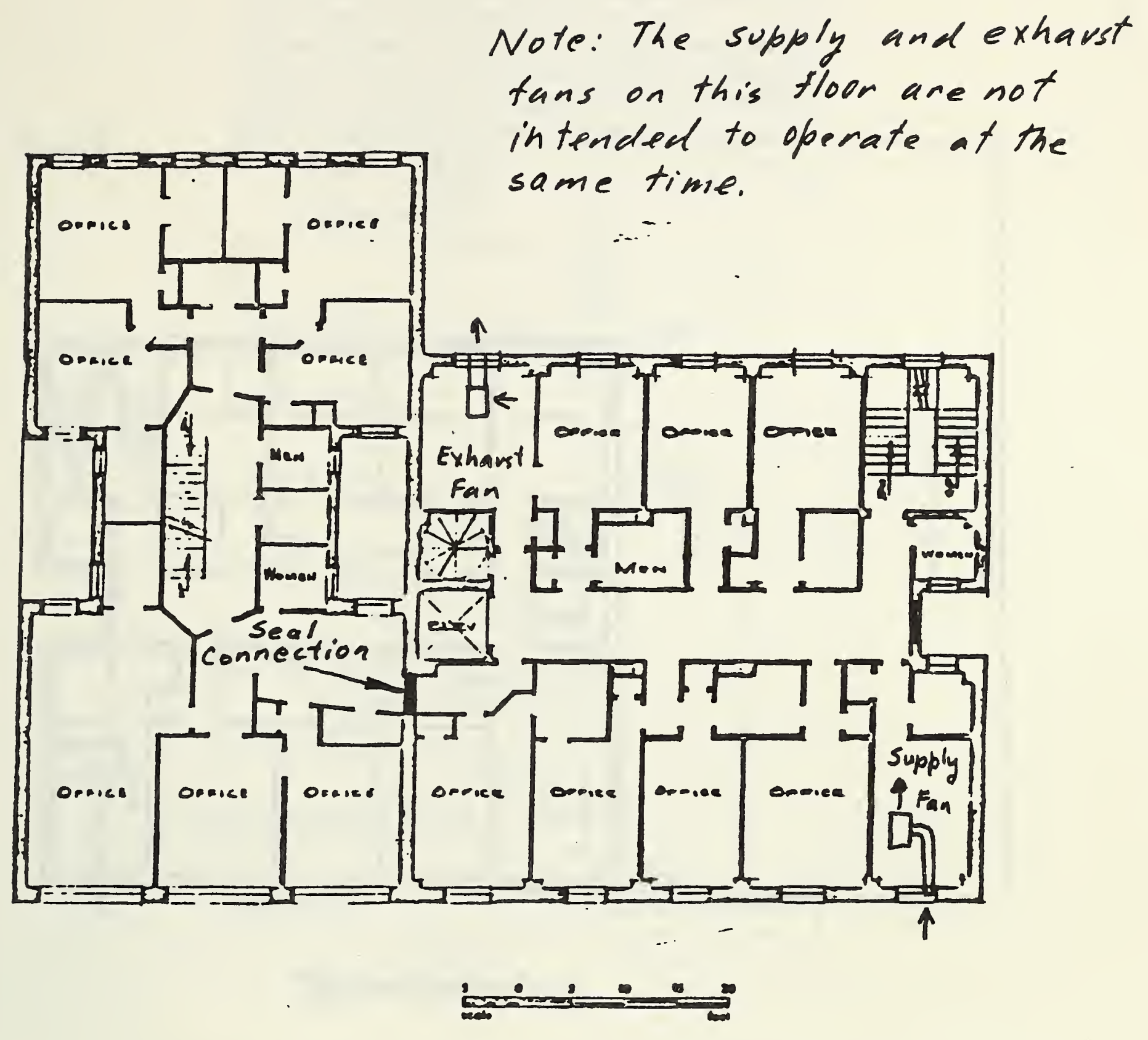

Figure 4. Plaza Hotel building third floor plan 


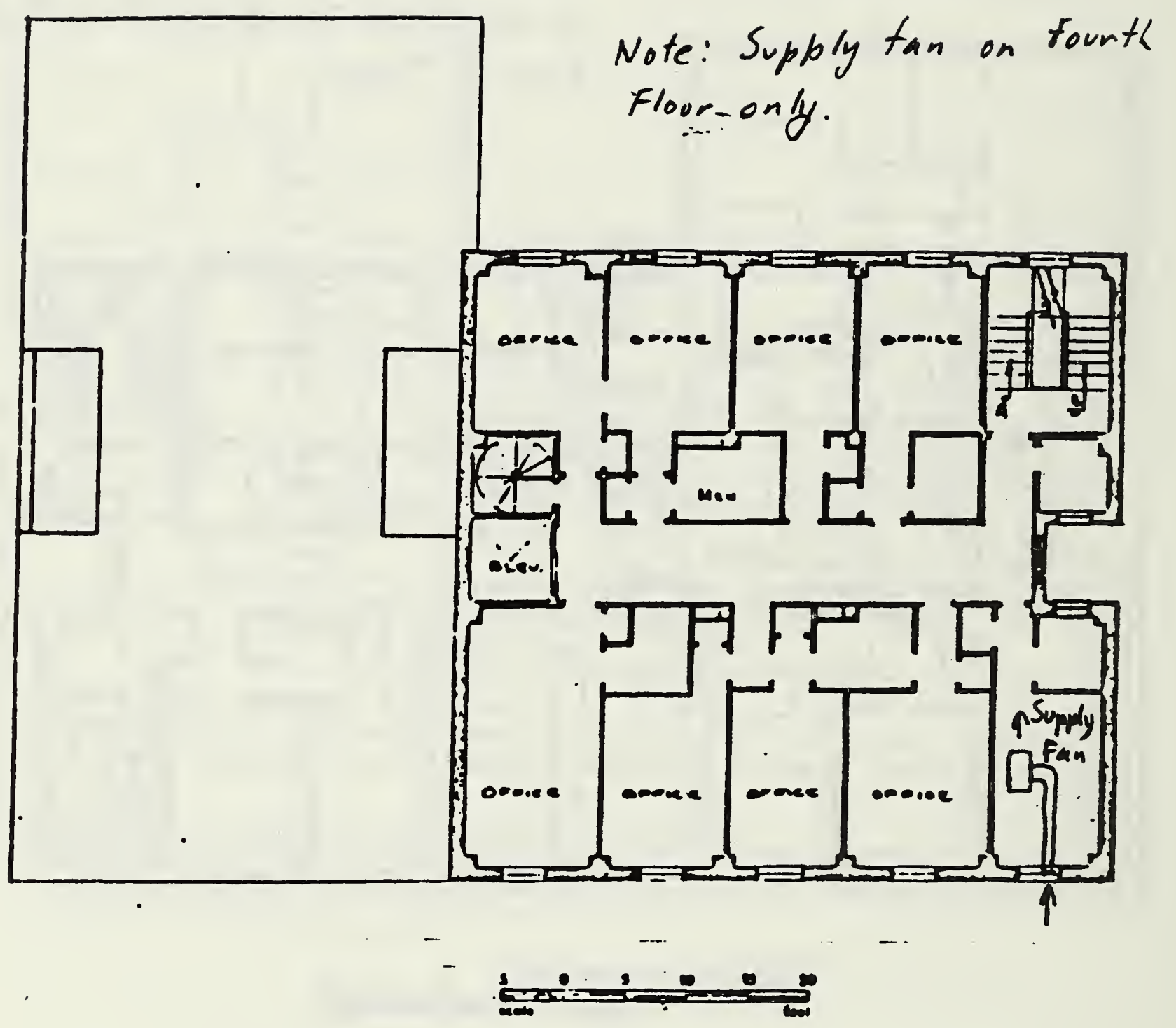

Figure 5. Plaza Hotel building typical floor plan for floors four through seven 
Notes:

1. The second floor is the smoke zone, and it is exhausted at six air changes per hour.

2. The first and second floors are pressurized at six air changes per hour.

3. The stairwell is pressurized by $9000 \mathrm{cfm}$, and the exterior stairwell door remains open throughout pressurization.

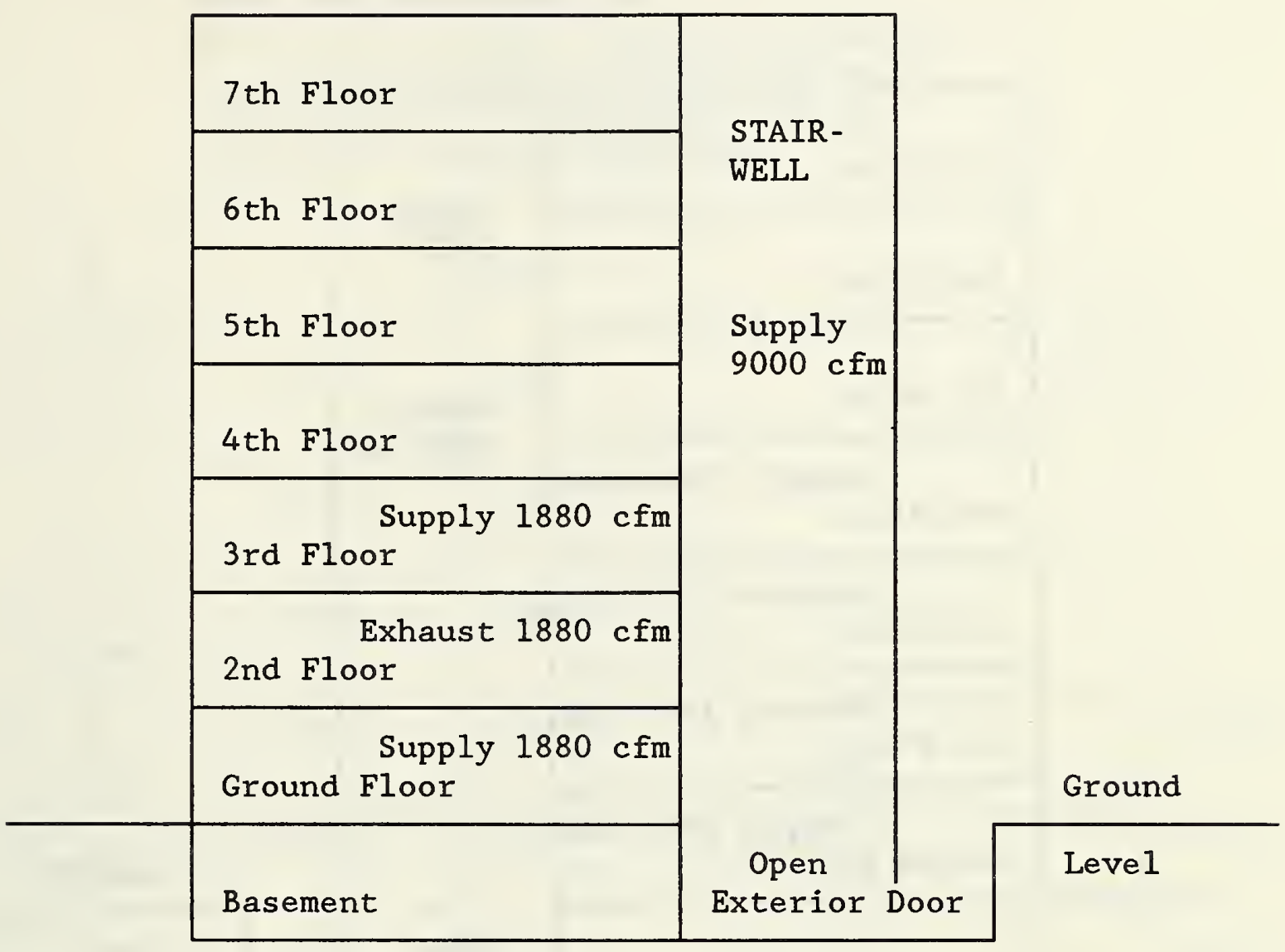

Figure 6. Conceptual smoke control systems with the smoke zone being the fire floor 


\section{Notes:}

1. The second floor is the fire floor. The smoke zone consists of the second and third floors, and both floors are exhausted at six air changes per hour.

2. The first and fourth floors are pressurized at six air changes per hour.

3. The stairwell is pressurized by $9000 \mathrm{cfm}$, and the exterior stairwell door remains open throughout pressurization.

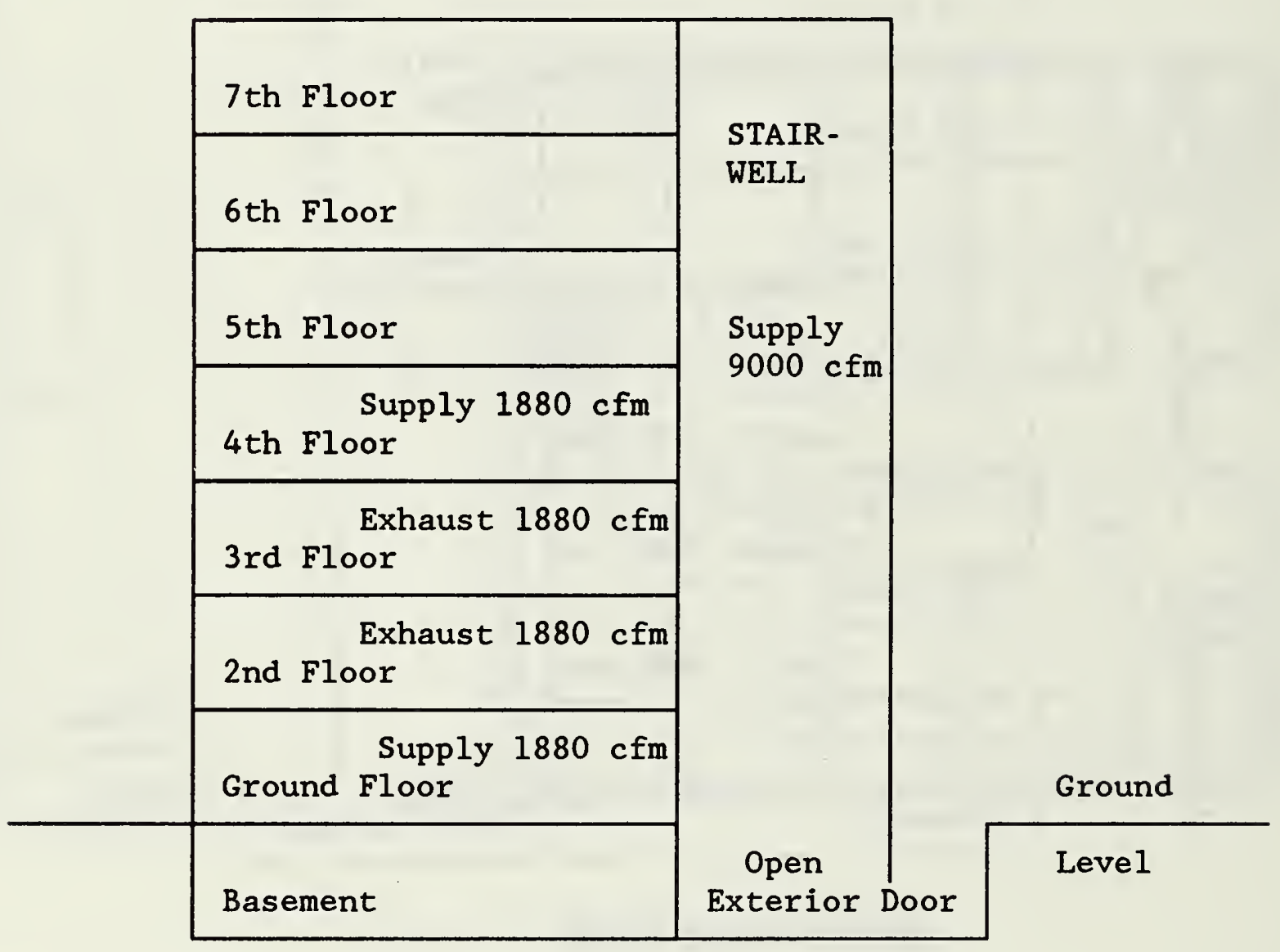

Figure 7. Conceptual smoke control systems with the smoke zone being the fire floor and the floor above 
Notes:

1. The numbers in the diagram are areas in feet squared for the loose building leakage values (see table 1 ).

2. The effective network is calculated by the methods described in section 2.6 of the ASHRAE Smoke Control Manual (Klote and Fothergill 1983).

3. The leakage areas between floors are not shown in the effective network because the pressure differences across these areas are kept at zero as part of the calibration process to determine the leakage area between the second floor and the outside.

4. Using the flow equation $\left(\dot{\mathrm{m}}=\mathrm{CA}(2 \rho \Delta \mathrm{P})^{\frac{1}{2}}\right)$, the flow rates $\left(\dot{\mathrm{m}}_{1}\right.$, $\dot{\mathrm{m}}_{2}$ and $\dot{\mathrm{m}}_{3}$ ) of pressurization air for calibration can be estimated for any particular pressure difference.

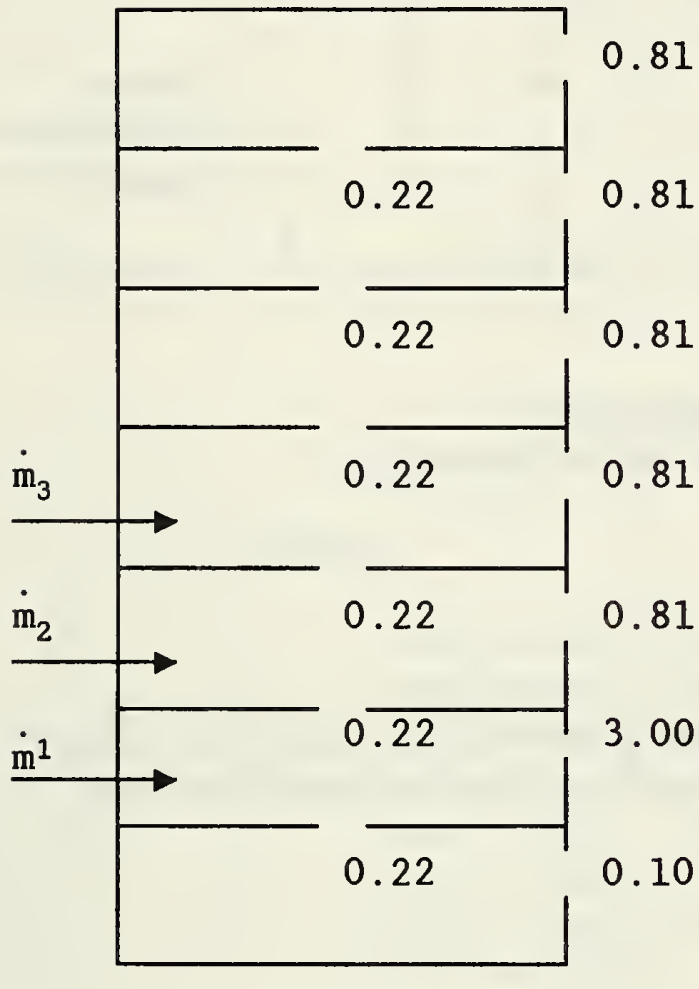

Flow Network for Calibration Conditions

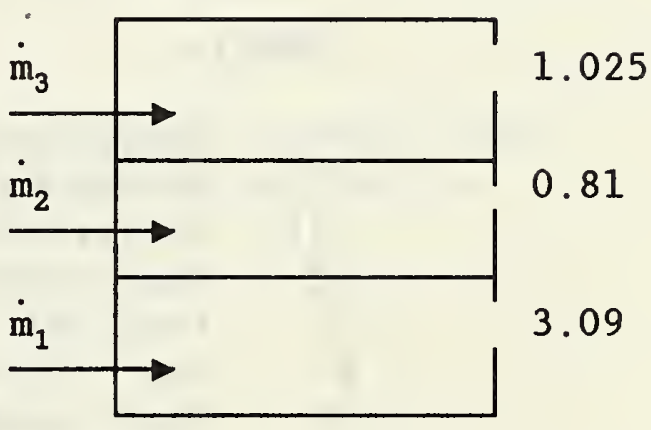

Effective Flow Network for Calibration Conditions

Figure 8. Effective flow network for estimating magnitude of pressurization needed during calibration 
Floor

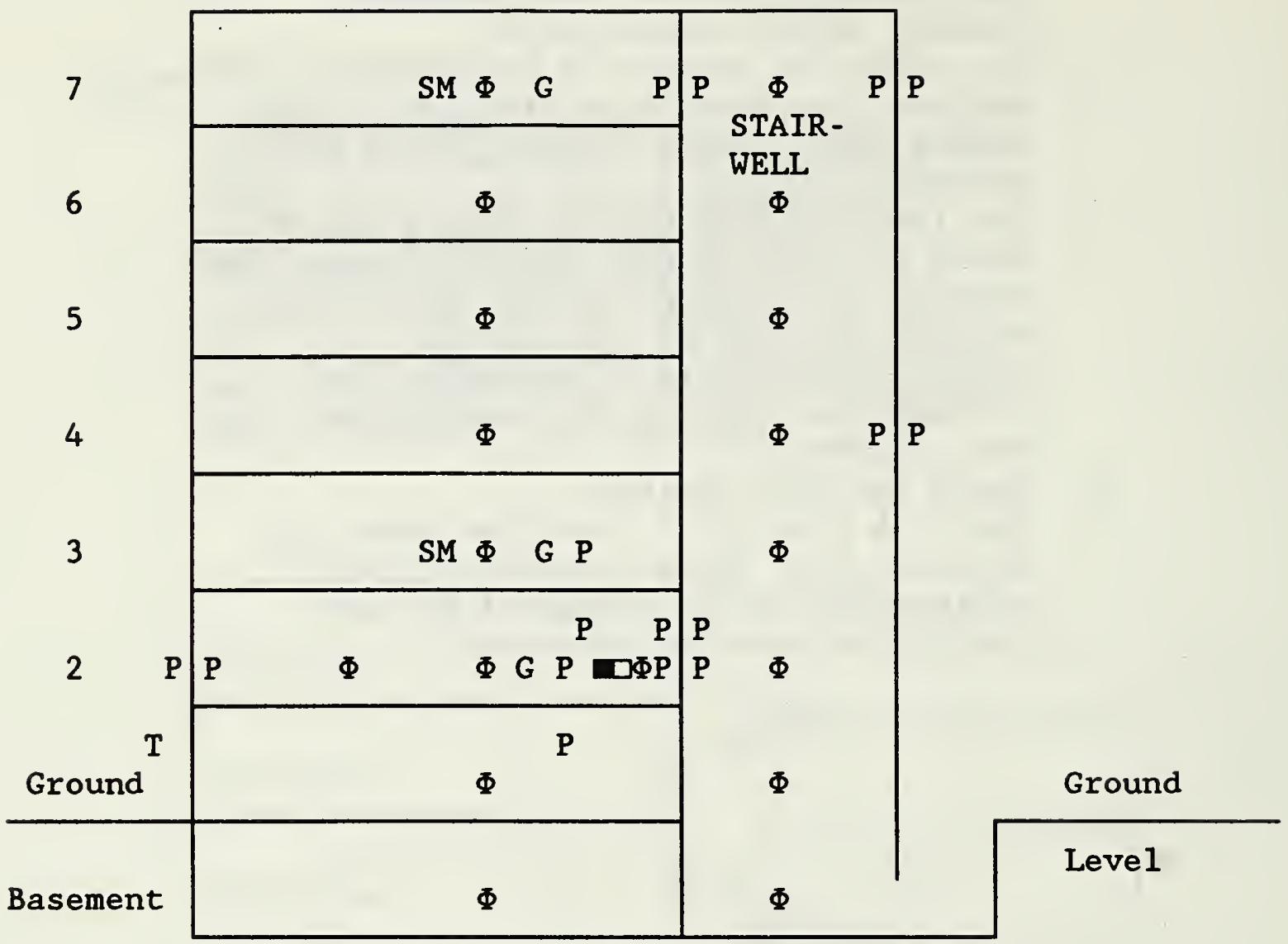

Note: Volumetric flow and temperature instrumentation for the smoke control system are not shown.

Symbols

$\Phi \quad$ Thermocouple tree

G Gas probe $\mathrm{O}_{2}$ and $\mathrm{CO}$ plus $\mathrm{CO}_{2}$ on the fire floor

$\mathrm{P} \mid \mathrm{P}$ Differential pressure probes across barrier

SM Smoke obscuration

口 Load cell

- Gas burner

W Wind transducer

T Thermocouple

Figure 9. Conceptual instrumentation configuration for smoke control tests 


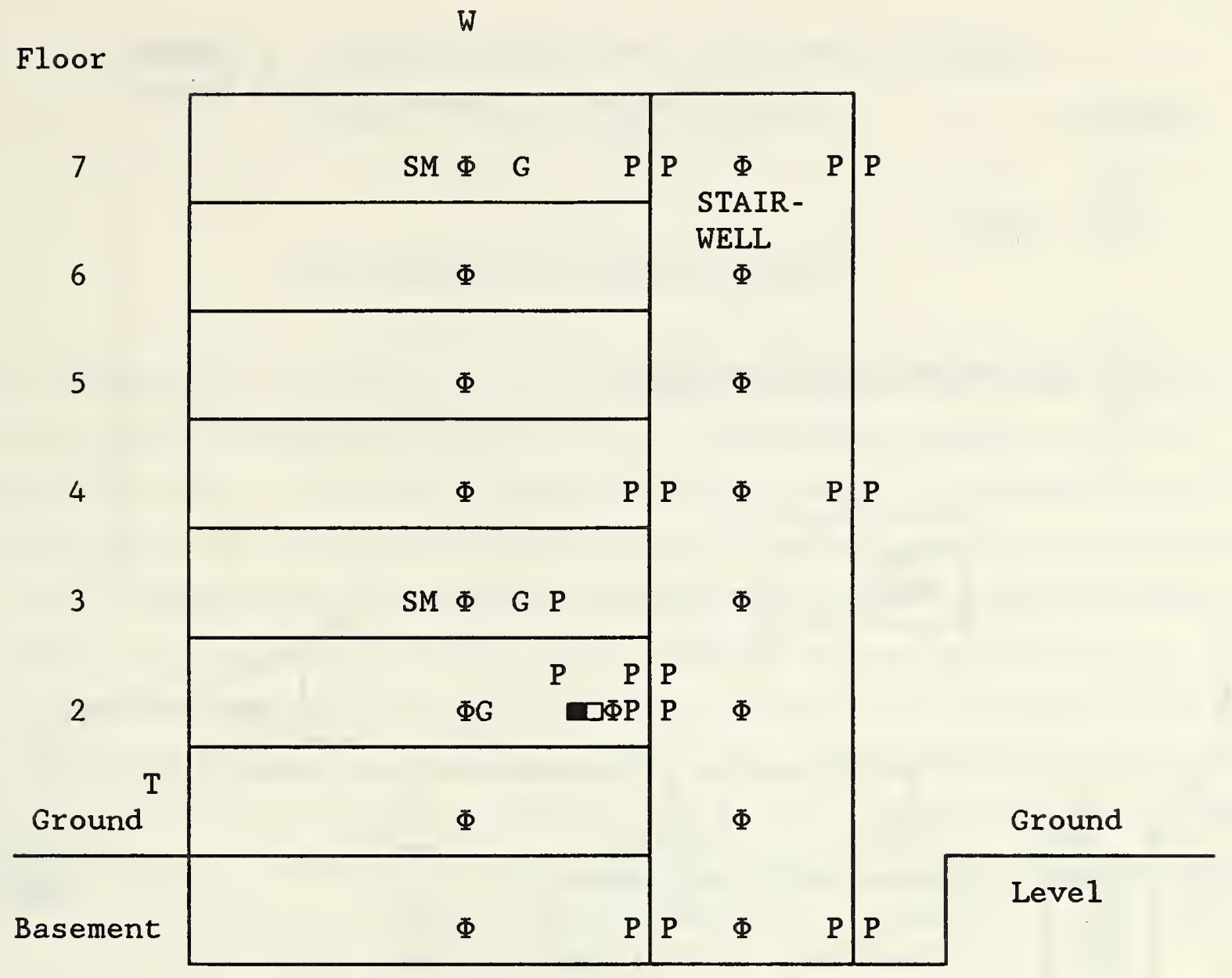

Symbols

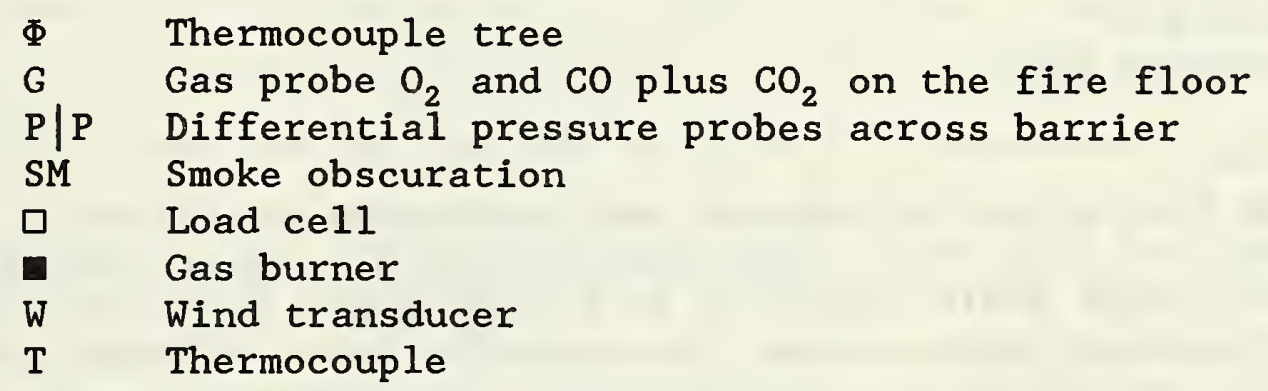

Figure 10. Conceptual instrumentation configuration for smoke movement tests 
Symbols :

Gas Probe
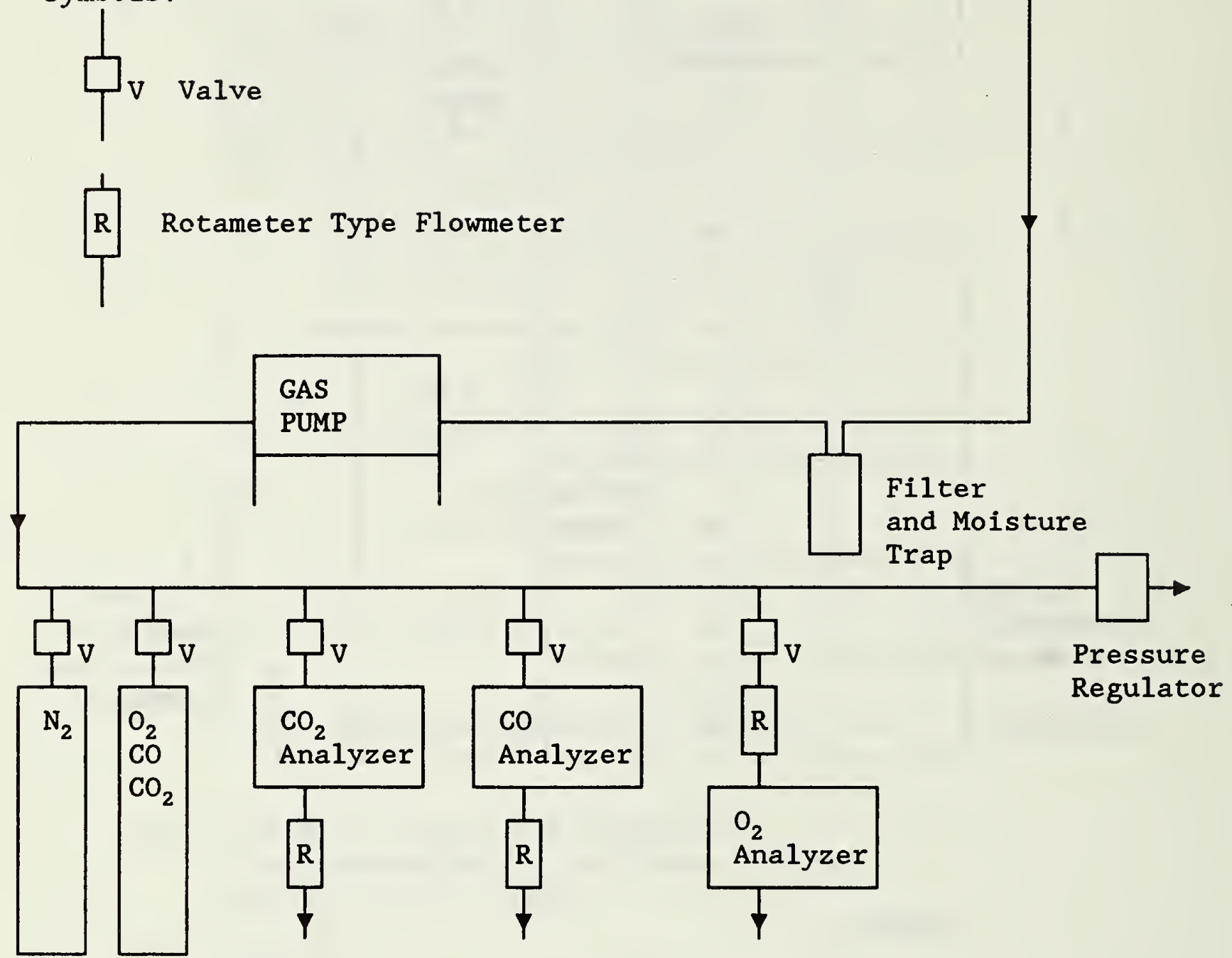

Cylinders of

Calibration Gases

Note:

The flow rates through the analyzers are required to be in the range of $2 \mathrm{ft}^{3} / \mathrm{hr}$. Flow rates through the entire piping system in this range would result in long time lags. The above piping arrangement with a pump flow rate of about $1 \mathrm{ft}^{3} / \mathrm{min}$ reduces lag time considerably. Theoretically, the rotameter can be upstream or downstream of the gas analyzer. Because of sensitivity to outlet pressure, the rotameter is upstream of the $\mathrm{O}_{2}$ analyzer.

Figure 11. Schematic piping arrangement for gas analysis equipment 


\section{APPENDIX A COMPUTER OUTPUT FOR PLAZA HOTEL BUILDING SMOKE CONTROL SYSTEM ANALYSIS}

\section{Description of Computer Output}

For the computer analyses of this appendix, the outside temperature is $40.0^{\circ} \mathrm{F}$, the inside temperature is $70.0^{\circ} \mathrm{F}$. The network consists of one compartment per floor, a stairwell and an elevator shaft. The flow areas that connect the spaces of this network are listed in table 1 , and the conditions of the runs are described in table 2. The flow coefficients for all the leakage paths were selected at 0.65 . The computer output consists of a description of the building network with the pressures at each space and the steady flow rates between all the spaces that are connected by leakage paths. A complete description of ASCOS including the output is provided in the ASHRAE Smoke Control Manual, however the following limited description of the output is provided as a convenience to the reader.

For each run, the output consists of data about the building spaces (spaces other than shafts), followed by data about each shaft. On the top of the page 31, the output for run 1 shows all the connections to compartment 1 of floor 1. (Because of a limitation of the ASCOS program, floor 1 of the output is actually the basement of the building - floor 2 is actually the first floor, and the others follow the same pattern.) A pressure difference of 0.37 in $\mathrm{H}_{2} \mathrm{O}$ is listed from compartment 1 of floor 2 to compartment 1 of floor 1. The leakage area of the connection is $0.220 \mathrm{ft}^{2}$, and the resulting flow is $109.8 \mathrm{scfm}$ (at $70^{\circ} \mathrm{F}$ and 1 atmosphere). Similar information is provided for the connections from compartment 1 of floor 1 to the stairwell, the elevator shaft, and the outside. Finally, the net of all these flows into compartment 1 on floor 1 is listed at $-0.3 \mathrm{scfm}$. The program is a steady flow analysis, and this net flow is printed to show the level of convergence of the computer generated solution and to give users confidence in the solution. 
Similar data is provided for all the other floors of the building. Compartment 1 of floor 2 is pressurized at $1880 \mathrm{cfm}$, and this is indicated by the fixed flow listed in the output. The floor above is exhausted, and this is indicated in the output as a fixed flow of $-1880 \mathrm{cfm}$. These fixed flows were part of the input data, and they are included in the output for the convenience of the user.

Output for the stairwell has a similar pattern. The fixed flow of 9000 cfm for the top floor of the stairwell indicate that it is pressurized at the top. The shaft flow coefficient allows the program to incorporate friction loss in shafts and is part of the input data. The net flow for the entire stairwell, reflecting the fact that ASCOS calculates mass from the steady flow conservation of mass equation applied to the entire stairwell. 
RUN 1 - PLAZA HOTEL - ALL DOORS CLOSED - LOOSE CONSTRUCTION

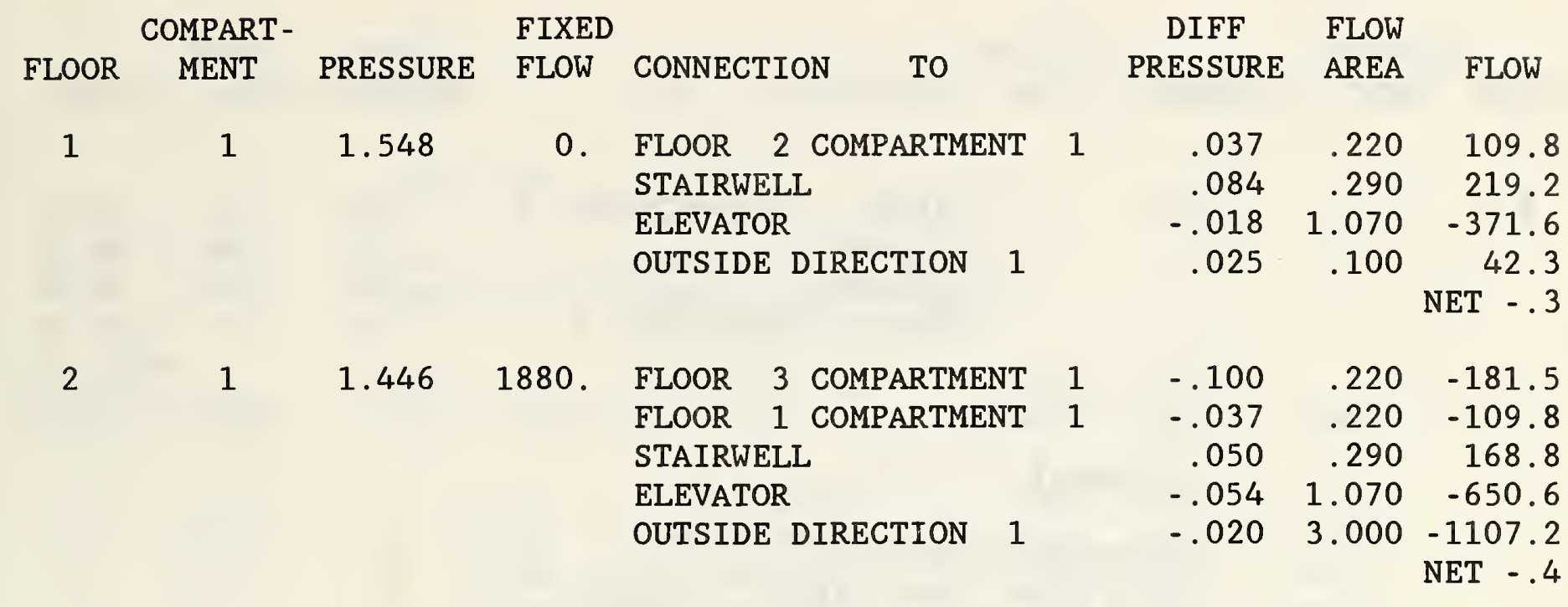

1

$1.208-1880$

FLOOR 4 COMPARTMENT 1

FLOOR 2 COM
STAIRWELL

ELEVATOR

OUTSIDE DIRECTION 1

$.151 \quad .220$

223.0

$.100 \quad .220$

181.5

.153

.290

295.3

.046

1.070

596.6

.072

.810

583.2

NET -.3 .

$4 \quad 1$

$1.221 \quad 1880$.

FLOOR 5 COMPARTMENT 1

$-.094$

.220

$-176.2$

FLOOR 3 COMPARTMENT 1

STAIRWELL

ELEVATOR

$-.151 \quad .220$

$-223.0$

.004

49.0

OUTSIDE DIRECTION 1

$-.106$

.290

$-905.9$

$-.087$

1.070

$-624.3$

NET - . 4

$\begin{array}{lll}5 & 1 & .988\end{array}$

0. FLOOR 6 COMPARTMENT 1

FLOOR 4 COMPARTMENT 1

STAIRWELL

ELEVATOR

OUTSIDE DIRECTION 1

$-.007$

.094

.220

$-49.1$

.102

.220

176.2

$-.011$

.290

240.8

$-.001$

1.070

$-295.2$

$.810 \quad-72.9$

NET -. 3

$\begin{array}{lll}6 & 1 & .843\end{array}$

0. FLOOR 7 COMPARTMENT 1

$-.003$

.220

$-31.5$

FLOOR 5 COMPARTMENT 1

.007

.220

49.1

.112

.290

253.0

ELEVATOR

$-.004$

1.070

$-176.2$

OUTSIDE DIRECTION 1

$-.002$

.810

$-94.7$

NET -.3

$\begin{array}{lll}7 & 1 & .701\end{array}$

0. FLOOR 8 COMPARTMENT

FLOOR 6 COMPARTMENT 1

STAIRWELL

ELEVATOR

$-.001$

.220

$-19.5$

.003

.220

31.5

.119

.290

260.2

OUTSIDE DIRECTION 1

$-.001 \quad 1.070$

$-93.8$

$-.007$

.810

$-178.8$ $\mathrm{NET}-.31$ 
RUN 1 - PLAZA HOTEL - ALL DOORS CLOSED - LOOSE CONSTRUCTION

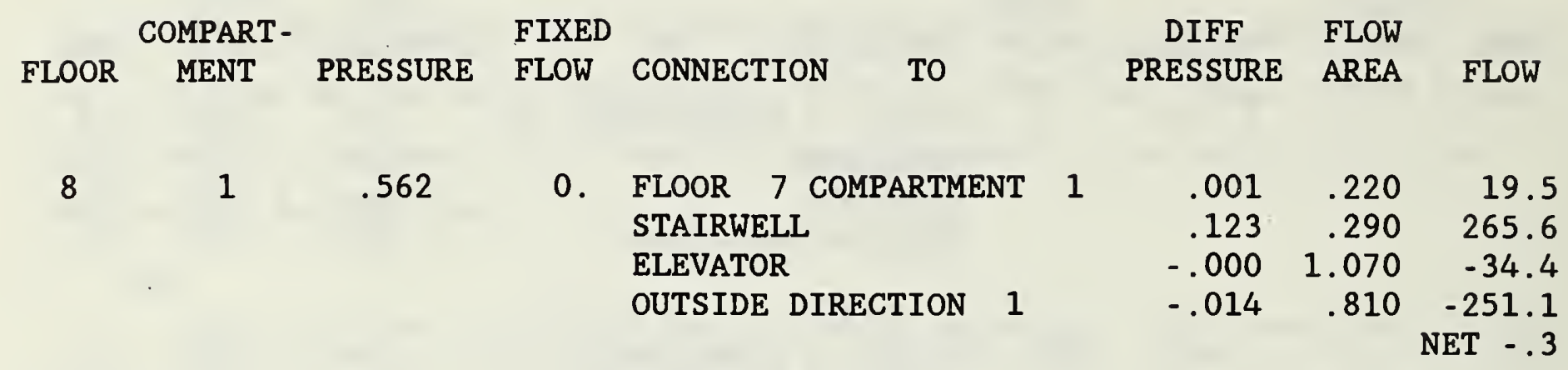

STAIRWELL

TEMPERATURE PROFILE 1

SHAFT FLOW COEFFICIENT 140000.

\begin{tabular}{|c|c|c|c|c|c|c|c|}
\hline & PRF CSIIR F & FIXED & CONNFCTTON & & $\begin{array}{c}\text { DIFF } \\
\text { PRFSIRF }\end{array}$ & FLOW & FT OW \\
\hline \multirow[t]{2}{*}{1} & 1.632 & 0 . & FLOOR 1 COMPARTMENT & 1 & -.084 & .290 & -219.2 \\
\hline & & & OUTSIDE DIRECTION 1 & & -.059 & 10.500 & -6665.9 \\
\hline \multirow[t]{2}{*}{2} & 1.496 & 0. & FLOOR 2 COMPARTMENT & 1 & -.050 & .290 & -168.8 \\
\hline & & & OUTSIDE DIRECTION 1 & & -.070 & .100 & -68.9 \\
\hline \multirow[t]{2}{*}{3} & 1.360 & 0 . & FLOOR 3 COMPARTMENT & 1 & -.153 & .290 & -295.3 \\
\hline & & & OUTSIDE DIRECTION 1 & & -.081 & .100 & -74.0 \\
\hline \multirow[t]{2}{*}{4} & 1.225 & 0 . & FLOOR 4 COMPARTMENT & 1 & -.004 & .290 & -49.0 \\
\hline & & & OUTSIDE DIRECTION 1 & & -.092 & .100 & -78.9 \\
\hline \multirow[t]{2}{*}{5} & 1.090 & 0 . & FLOOR 5 COMPARTMENT & 1 & -.102 & .290 & -240.8 \\
\hline & & & OUTSIDE DIRECTION 1 & & -.103 & .100 & -83.5 \\
\hline \multirow[t]{2}{*}{6} & .955 & 0 . & FLOOR 6 COMPARTMENT & 1 & -.112 & .290 & -253.0 \\
\hline & & & OUTSIDE DIRECTION 1 & & -.114 & .100 & -88.0 \\
\hline \multirow[t]{2}{*}{7} & .820 & 0. & FLOOR 7 COMPARTMENT & 1 & -.119 & .290 & -260.2 \\
\hline & & & OUTSIDE DIRECTION 1 & & -.126 & .100 & -92.4 \\
\hline \multirow[t]{2}{*}{8} & .686 & 9000 . & FLOOR 8 COMPARTMENT & 1 & -.123 & .290 & -265.6 \\
\hline & & & OUTSIDE DIRECTION 1 & & -.138 & .100 & -96.7 \\
\hline
\end{tabular}

THE FOLLOWING UNITS ARE USED FOR OUTPUT

FLOW IN CFM AT 70 DEG F AND 1 ATM

PRESSURE IN INCHS H2O

AREA IN FEET SQUARED 
RUN 1 - PLAZA HOTEL - ALL DOORS CLOSED - LOOSE CONSTRUCTION

ELEVATOR

TEMPERATURE PROFILE 1

SHAFT FLOW COEFFICIENT 140000.

\begin{tabular}{|c|c|c|c|c|c|c|c|c|c|}
\hline \multirow[b]{2}{*}{ FLOOR } & \multicolumn{2}{|r|}{ FIXED } & \multirow{2}{*}{\multicolumn{3}{|c|}{ CONNECTION }} & \multicolumn{2}{|r|}{ DIFF } & \multicolumn{2}{|l|}{ FLOW } \\
\hline & PRESSURE & FLOW & & & & & PRESSURE & AREA & FLOW \\
\hline 1 & 1.530 & 0 . & FLOOR & 1 & COMPARTMENT & 1 & .018 & 1.070 & 371.6 \\
\hline 2 & 1.392 & 0 . & FLOOR & 2 & COMPARTMENT & 1 & .054 & 1.070 & 650.6 \\
\hline 3 & 1.253 & 0 . & FLOOR & 3 & COMPARTMENT & 1 & -.046 & 1.070 & -596.6 \\
\hline 4 & 1.115 & 0 . & FLOOR & 4 & COMPARTMENT & 1 & .106 & 1.070 & 905.9 \\
\hline 5 & .977 & 0 . & FLOOR & 5 & COMPARTMENT & 1 & .011 & 1.070 & 295.2 \\
\hline 6 & .839 & 0. & FLOOR & 6 & COMPARTMENT & 1 & .004 & 1.070 & 176.2 \\
\hline 7 & .700 & 0 . & FLOOR & 7 & COMPARTMENT & 1 & .001 & 1.070 & 93.8 \\
\hline 8 & .562 & 0 . & FLOOR & 8 & COMPARTMENT & 1 & .000 & 1.070 & 34.3 \\
\hline 9 & .424 & 0 . & & & & & & & \\
\hline & & & OUTSID & & DIRECTION & & -.022 & 5.000 & $\begin{array}{r}-1931.2 \\
-.1\end{array}$ \\
\hline
\end{tabular}

THE FOLLOWING UNITS ARE USED FOR OUTPUT

FLOW IN CFM AT 70 DEG F AND 1 ATM

PRESSURE IN INCHS H2O

AREA IN FEET SQUARED 
RUN 2 - PLAZA HOTEL - ALL DOORS CLOSED - AVERAGE CONSTRUCTION

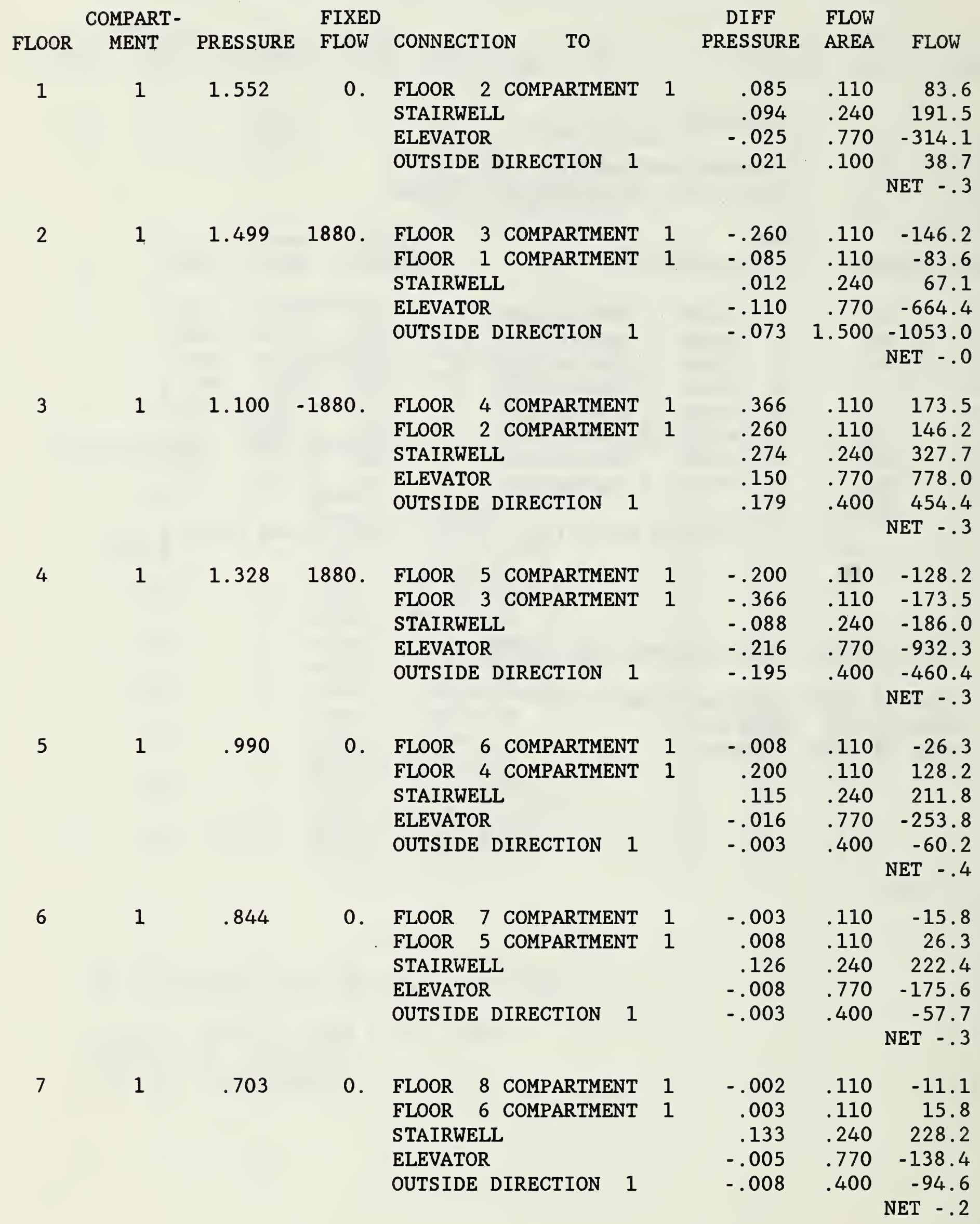


RUN 2 - PLAZA HOTEL - ALL DOORS CLOSED - AVERAGE CONSTRUCTION

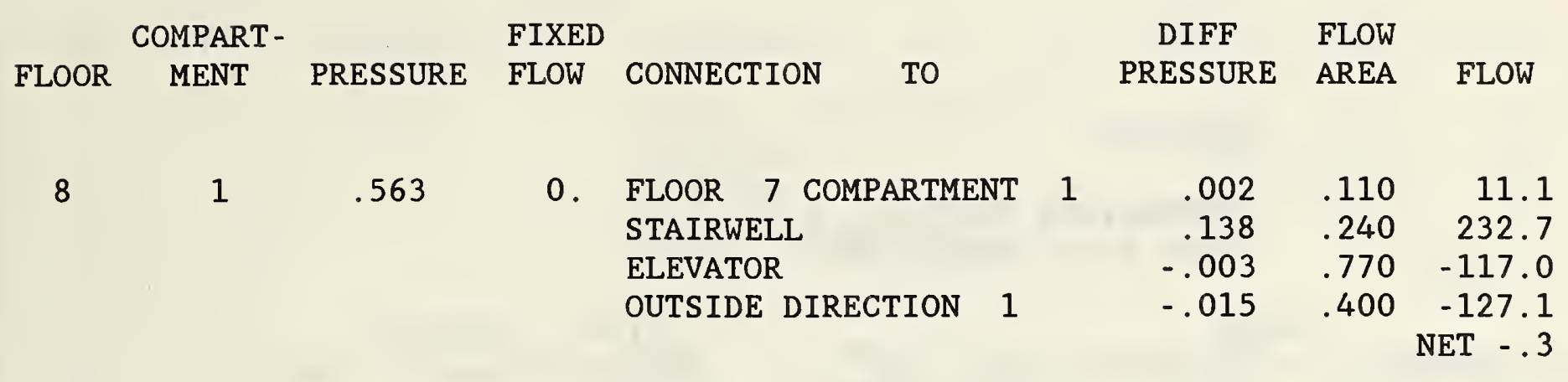

STAIRWELL

TEMPERATURE PROFILE 1

SHAFT FLOW COEFFICIENT 140000.

\begin{tabular}{|c|c|c|c|c|c|c|c|}
\hline & PRF SSUIRF & FIXED & CONNECTTON & & $\begin{array}{l}\text { DIFF } \\
\text { PRF SSIRF }\end{array}$ & FLOW & FI OWT \\
\hline \multirow[t]{2}{*}{1} & 1.646 & 0 . & FLOOR 1 COMPARTMENT & 1 & -.094 & .240 & -191.5 \\
\hline & & & OUTSIDE DIRECTION 1 & & -.073 & 10.500 & -7392.4 \\
\hline \multirow[t]{2}{*}{2} & 1.510 & 0 . & FLOOR 2 COMPARTMENT & 1 & -.012 & .240 & -67.1 \\
\hline & & & OUTSIDE DIRECTION 1 & & -.084 & .050 & -37.8 \\
\hline \multirow[t]{2}{*}{3} & 1.375 & 0 . & FLOOR 3 COMPARTMENT & 1 & -.274 & .240 & -327.7 \\
\hline & & & OUTSIDE DIRECTION 1 & & -.095 & .050 & -40.2 \\
\hline \multirow[t]{2}{*}{4} & 1.240 & 0 . & FLOOR 4 COMPARTMENT & 1 & .088 & .240 & 186.0 \\
\hline & & & OUTSIDE DIRECTION 1 & & -.107 & .050 & -42.6 \\
\hline \multirow[t]{2}{*}{5} & 1.105 & 0 . & FLOOR 5 COMPARTMENT & 1 & -.115 & .240 & -211.8 \\
\hline & & & OUTSIDE DIRECTION 1 & & -.118 & .050 & -44.8 \\
\hline \multirow[t]{2}{*}{6} & .970 & 0. & FLOOR 6 COMPARTMENT & 1 & -.126 & .240 & -222.4 \\
\hline & & & OUTSIDE DIRECTION 1 & & -.130 & .050 & -46.9 \\
\hline \multirow[t]{2}{*}{7} & .836 & 0. & FLOOR 7 COMPARTMENT & 1 & -.133 & .240 & -228.2 \\
\hline & & & OUTSIDE DIRECTION 1 & & -.141 & .050 & -49.0 \\
\hline \multirow[t]{2}{*}{8} & .701 & 9000 . & FLOOR 8 COMPARTMENT & 1 & -.138 & .240 & -232.7 \\
\hline & & & OUTSIDE DIRECTION 1 & & -.153 & .050 & -51.0 \\
\hline
\end{tabular}

THE FOLLOWING UNITS ARE USED FOR OUTPUT

FLOW IN CFM AT 70 DEG F AND 1 ATM

PRESSURE IN INCHS H2O

AREA IN FEET SQUARED 
RUN 2 - PLAZA HOTEL - ALL DOORS CLOSED - AVERAGE CONSTRUCTION

\section{ELEVATOR}

TEMPERATURE PROFILE 1 SHAFT FLOW COEFFICIENT 140000.

\begin{tabular}{|c|c|c|c|c|c|c|c|c|}
\hline & PRFSSURF & FIXED & CONNFCTIO & $\mathrm{TO}$ & & $\begin{array}{c}\text { DIFF } \\
\text { PRFSSIRF }\end{array}$ & FLOW & Fi 0 OW \\
\hline 1 & 1.527 & 0. & FLOOR & COMPARTMENT & 1 & .025 & .770 & 314.1 \\
\hline 2 & 1.389 & 0. & FLOOR & COMPARTMENT & 1 & .110 & .770 & 664.4 \\
\hline 3 & 1.251 & 0 . & FLOOR & COMPARTMENT & 1 & -.150 & .770 & -778.0 \\
\hline 4 & 1.113 & 0. & FLOOR & COMPARTMENT & 1 & .216 & .770 & 932.3 \\
\hline 5 & .974 & 0. & FLOOR & COMPARTMENT & 1 & .016 & .770 & 253.8 \\
\hline 6 & .836 & 0. & FLOOR & COMPARTMENT & 1 & .008 & .770 & 175.6 \\
\hline 7 & .698 & 0 . & FLOOR & COMPARTMENT & 1 & .005 & .770 & 138.4 \\
\hline 8 & .560 & 0. & FLOOR & COMPARTMENT & 1 & .003 & .770 & 117.0 \\
\hline & .421 & 0. & & & & & & \\
\hline & & & OUTSIDE D & DIRECTION & & -.019 & 5.000 & -1817 \\
\hline
\end{tabular}

THE FOLLOWING UNITS ARE USED FOR OUTPUT

FLOW IN CFM AT 70 DEG F AND 1 ATM

PRESSURE IN INCHS H2O

AREA IN FEET SQUARED 
RUN 3 - PLAZA HOTEL - DOORS OPENED - LOOSE CONSTRUCTION

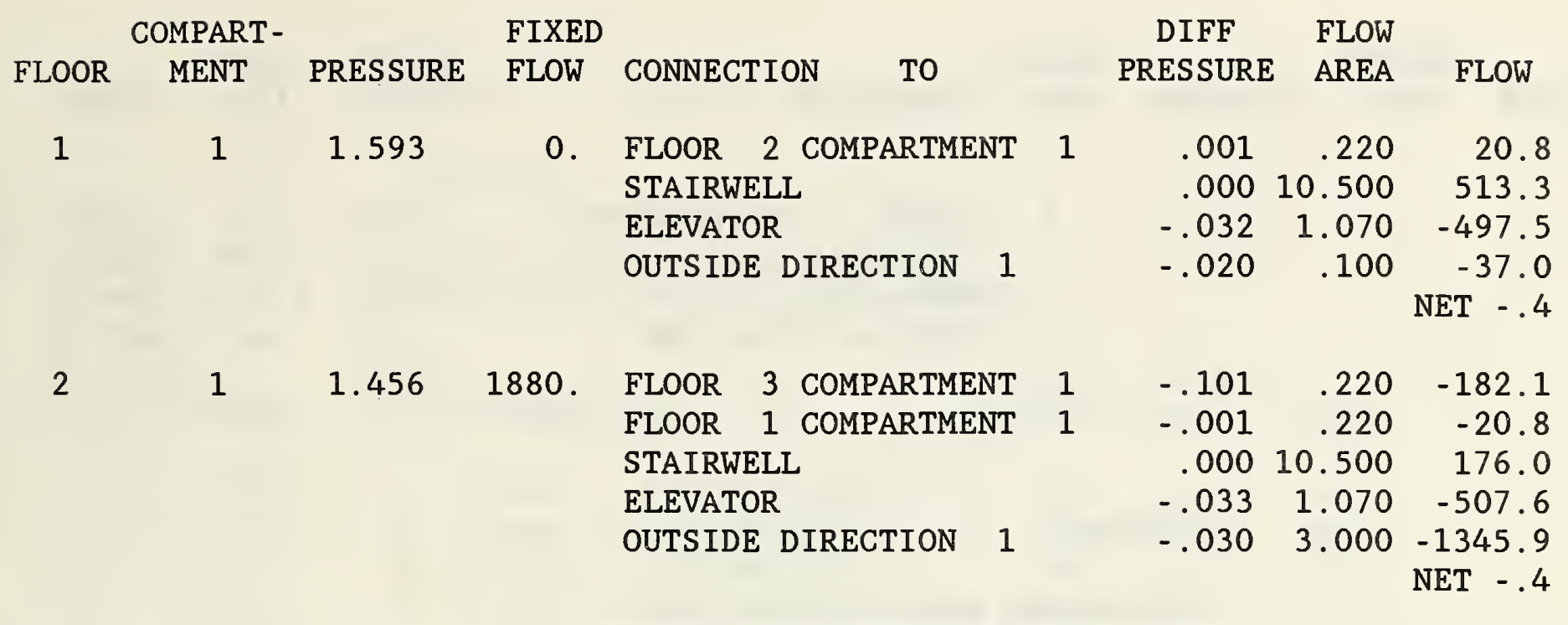

FLOOR 4 COMPARTMENT 1

FLOOR 2 COMPARTMENT 1 STAIRWELL

ELEVATOR

OUTSIDE DIRECTION 1

$.104 \quad .220$

184.8

$\begin{array}{lll}.101 & .220 \quad 182.1\end{array}$

$.102 \quad .290 \quad 241.4$

$\begin{array}{lll}.068 & 1.070 \quad 725.6\end{array}$

$.063 \quad .810 \quad 545.9$

NET - . 1 .

4

1

1.1821880 .

FLOOR 5 COMPARTMENT 1

FLOOR 3 COMPARTMENT 1

STAIRWELL

ELEVATOR

OUTSIDE DIRECTION 1

$-.000$

$-.000 . .220$

$-.104 \quad .220$

$-17.8$

$-.00010 .500-184.8$

$-.036 \quad 1.070 \quad-530.4$

$-.049 \quad .810 \quad-467.1$

NET -.2

$1 \quad 1.043$

0. FLOOR 6 COMPARTMENT 1

FLOOR 4 COMPARTMENT 1

STAIRWELL

ELEVATOR

OUTSIDE DIRECTION 1

$\begin{array}{rrr}.001 & .220 & 20.2 \\ .000 & .220 & 17.8 \\ .001 & 10.500 & 985.2 \\ -.035 & 1.070 & -523.5 \\ -.056 & .810 & -500.1 \\ & & \text { NET }-.4\end{array}$

$\begin{array}{lll}6 & 1 & .906\end{array}$

0. FLOOR 7 COMPARTMENT 1

$\begin{array}{rrr}.002 & .220 & 25.6 \\ -.001 & .220 & -20.2 \\ .002 & 10.500 & 1068.1 \\ -.037 & 1.070 & -533.2 \\ -.066 & .810 & -540.3 \\ & & \text { NET }-.1\end{array}$

$1 \quad .770$

0 .

STAIRWELL

ELEVATOR

OUTSIDE DIRECTION 1

$.003 \quad .220$

29.9

FLOOR 6 COMPARTMENT 1

$-.002$

.220

$-25.6$

STAIRWELL

.00210 .500

1124.9

ELEVATOR

$\begin{array}{lll}-.039 & 1.070 & -548.7\end{array}$

OUTSIDE DIRECTION 1

$-.076$

.810

$-580.7$

NET -. 1 
RUN 3 - PLAZA HOTEL - DOORS OPENED - LOOSE CONSTRUCTION

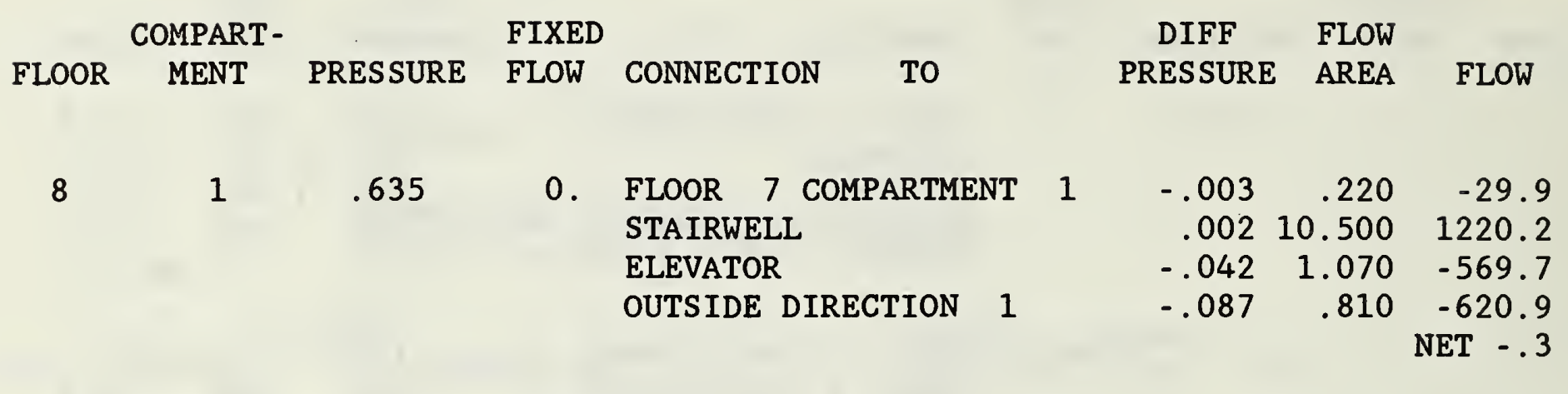

STAIRWELL

TEMPERATURE PROFILE 1

SHAFT FLOW COEFFICIENT 140000.

\begin{tabular}{|c|c|c|c|c|c|c|c|}
\hline \multirow[b]{2}{*}{ OOR } & \multicolumn{2}{|r|}{ FIXED } & & & DIFF & FLOW & \multirow[b]{2}{*}{ FLOW } \\
\hline & PRESSURE & FLOW & CONNECTION & & PRESSURE & AREA & \\
\hline \multirow[t]{2}{*}{1} & 1.593 & 0 . & FLOOR 1 COMPARTMENT & 1 & -.000 & 10.500 & -513.3 \\
\hline & & & OUTSIDE DIRECTION 1 & & -.020 & 10.500 & -3917.3 \\
\hline \multirow[t]{2}{*}{2} & 1.456 & 0. & FLOOR 2 COMPARTMENT & 1 & .000 & 10.500 & -176.0 \\
\hline & & & OUTSIDE DIRECTION 1 & & -.030 & .100 & -44.9 \\
\hline \multirow[t]{2}{*}{3} & 1.319 & 0 . & FLOOR 3 COMPARTMENT & 1 & -.102 & .290 & -241.4 \\
\hline & & & OUTSIDE DIRECTION 1 & & -.039 & .100 & -51.4 \\
\hline \multirow[t]{2}{*}{4} & 1.182 & 0 . & FLOOR 4 COMPARTMENT & 1 & .000 & 10.500 & 680.1 \\
\hline & & & OUTSIDE DIRECTION 1 & & -.048 & .100 & -57.3 \\
\hline \multirow[t]{2}{*}{5} & 1.044 & 0. & FLOOR 5 COMPARTMENT & 1 & -.001 & 10.500 & -985.2 \\
\hline & & & OUTSIDE DIRECTION 1 & & -.057 & .100 & -62.5 \\
\hline \multirow[t]{2}{*}{6} & .908 & 0 . & FLOOR 6 COMPARTMENT & 1 & -.002 & 10.500 & -1068.1 \\
\hline & & & OUTSIDE DIRECTION 1 & & -.067 & .100 & -67.5 \\
\hline \multirow[t]{2}{*}{7} & .772 & 0. & FLOOR 7 COMPARTMENT & 1 & -.002 & 10.500 & -1124.9 \\
\hline & & & OUTSIDE DIRECTION 1 & & -.077 & .100 & -72.5 \\
\hline \multirow[t]{2}{*}{8} & .637 & 9000 . & FLOOR 8 COMPARTMENT & 1 & -.002 & 10.500 & -1220.2 \\
\hline & & & OUTSIDE DIRECTION 1 & & -.089 & .100 & $\begin{array}{r}-77.5 \\
-.0\end{array}$ \\
\hline
\end{tabular}

THE FOLLOWING UNITS ARE USED FOR OUTPUT

FLOW IN CFM AT 70 DEG F AND 1 ATM

PRESSURE IN INCHS H2O

AREA IN FEET SQUARED 
RUN 3 - PLAZA HOTEL - DOORS OPENED - LOOSE CONSTRUCTION

ELEVATOR

TEMPERATURE PROFILE 1 SHAFT FLOW COEFFICIENT 140000.

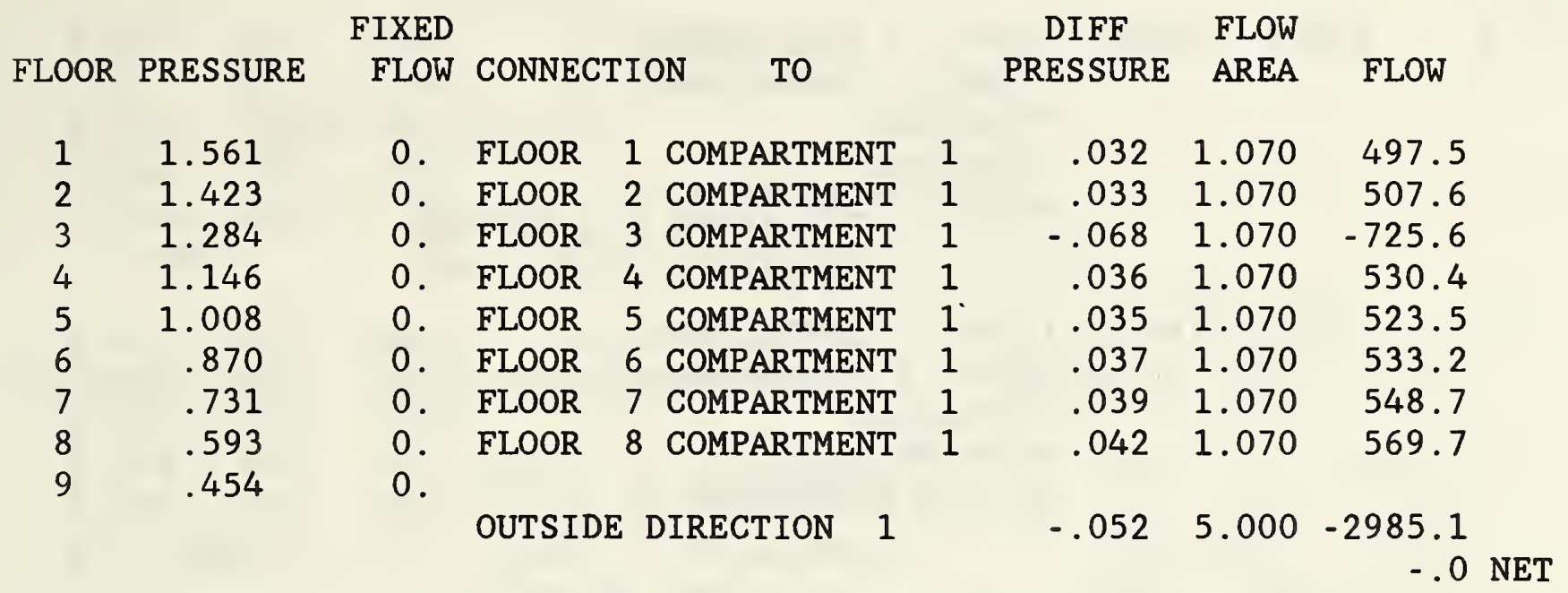

THE FOLLOWING UNITS ARE USED FOR OUTPUT

FLOW IN CFM AT 70 DEG F AND 1 ATM

PRESSURE IN INCHS H2O

AREA IN FEET SQUARED 
RUN 4 - PLAZA HOTEL - DOORS OPENED - AVERAGE CONSTRUCTION

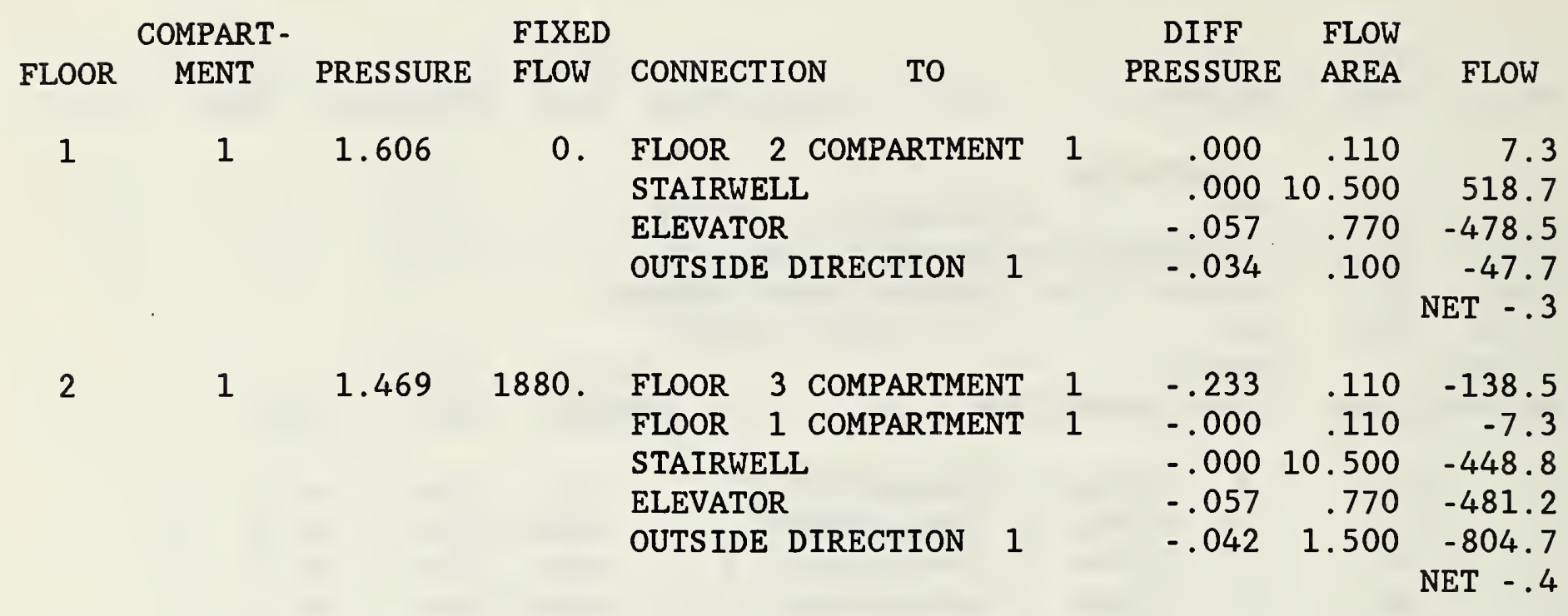

$1 \quad 1.097 \quad-1880$

$\begin{array}{lllllr}\text { FLOOR } 4 \text { COMPARTMENT } & 1 & .236 & .110 & 139.4 \\ \text { FLOOR 2 COMPARTMENT } & 1 & .233 & .110 & 138.5 \\ \text { STAIRWELL } & & & .233 & .240 & 301.9 \\ \text { ELEVATOR } & & .176 & .770 & 841.1 \\ \text { OUTSIDE DIRECTION } & 1 & & .183 & .400 & 458.7 \\ & & & & & \text { NET }-.4\end{array}$

4

1

1.1951880

FLOOR 5 COMPARTMENT 1

FLOOR 3 COMPARTMENT 1

STAIRWELL

ELEVATOR

OUTSIDE DIRECTION 1

$-.000$

.110

$-.236$

.110

$-.00110 .500$

$.061 \quad .770$
. .062

$-.062 \quad .400$

$-5.9$

$-139.4$

$-981.3$

$-494.4$

$-259.3$

NET -.4

5

$1 \quad 1.057$

0. FLOOR 6 COMPARTMENT 1

FLOOR 4 COMPARTMENT 1

STAIRWELL

ELEVATOR

OUTSIDE DIRECTION 1

$.002 \quad .110$

12.8

$.000 \quad .110$

5.9

$.00010 .500 \quad 748.5$

$-.060 \quad .770$

$-492.7$

$\begin{array}{lll}-.070 & .400 & -275.0\end{array}$

NET -.4

$\begin{array}{lll}6 & 1 & .920\end{array}$

0. FLOOR 7 COMPARTMENT 1

FLOOR 5 COMPARTMENT 1

STAIRWELL

ELEVATOR

OUTSIDE DIRECTION 1

$.003 \quad .110$

14.6

$-.002 \quad .110$

$-12.8$

$.00010 .500 \quad 793.1$

$\begin{array}{lll}-.062 & .770 & -500.9\end{array}$

$\begin{array}{lll}-.080 & .000 \quad-294.3\end{array}$

NET -.4

0 .

$\begin{array}{llrrrr}\text { FLOOR } 8 \text { COMPARTMENT } & 1 & .003 & .110 & 16.3 \\ \text { FLOOR } 6 \text { COMPARTMENT } & 1 & -.003 & .110 & -14.6 \\ \text { STAIRWELL } & & .000 & 10.500 & 823.4 \\ \text { ELEVATOR } & & & -.065 & .770 & -511.7 \\ \text { OUTSIDE DIRECTION } & 1 & & -.090 & .400 & -313.6 \\ & & & & & \end{array}$


RUN 4 - PLAZA HOTEL - DOORS OPENED - AVERAGE CONSTRUCTION

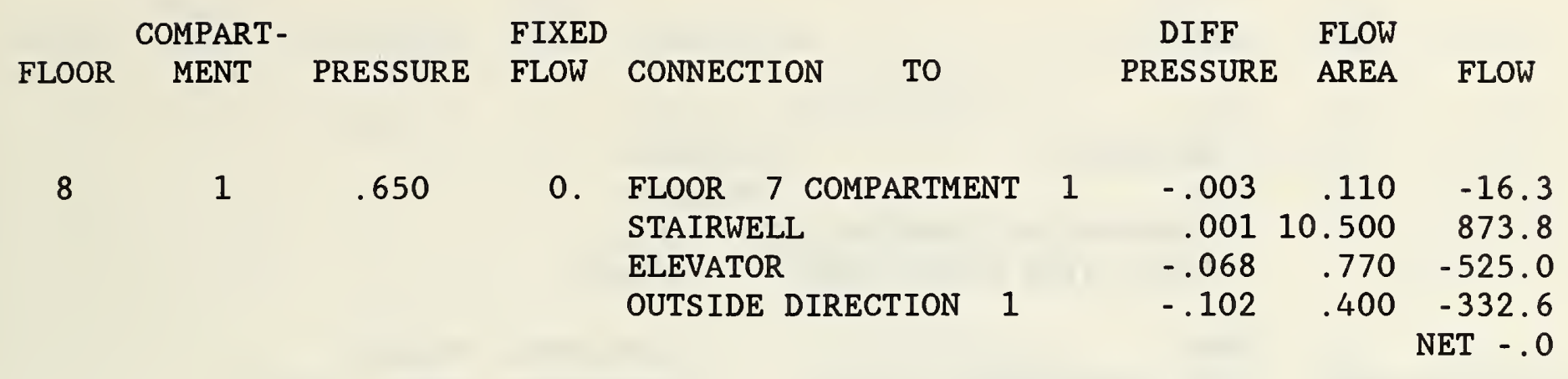

STAIRWELL

TEMPERATURE PROFILE 1

SHAFT FLOW COEFFICIENT 140000.

\begin{tabular}{|c|c|c|c|c|c|c|c|}
\hline \multirow[b]{2}{*}{ FLOOR } & \multicolumn{2}{|r|}{ FIXED } & & & DIFF & FLOW & \multirow[b]{2}{*}{ FLOW } \\
\hline & PRESSURE & FLOW & CONNECTION & & PRESSURE & AREA & \\
\hline \multirow[t]{2}{*}{1} & 1.607 & 0 . & FLOOR 1 COMPARTMENT & 1 & -.000 & 10.500 & -518.7 \\
\hline & & & OUTSIDE DIRECTION 1 & & -.034 & .050 & -24.0 \\
\hline \multirow[t]{2}{*}{2} & 1.468 & 0 . & FLOOR 2 COMPARTMENT & 1 & .000 & 10.500 & 448.8 \\
\hline & & & OUTSIDE DIRECTION 1 & & -.042 & .050 & -26.7 \\
\hline \multirow[t]{2}{*}{3} & 1.330 & 0 . & FLOOR 3 COMPARTMENT & 1 & -.233 & .240 & -301.9 \\
\hline & & & OUTSIDE DIRECTION 1 & & -.050 & 10.500 & -6135.2 \\
\hline \multirow[t]{2}{*}{4} & 1.194 & 0 . & FLOOR 4 COMPARTMENT & 1 & .001 & 10.500 & 981.3 \\
\hline & & & OUTSIDE DIRECTION 1 & & -.061 & .050 & -32.1 \\
\hline \multirow[t]{2}{*}{5} & 1.057 & 0 . & FLOOR 5 COMPARTMENT & 1 & -.000 & 10.500 & -748.5 \\
\hline & & & OUTSIDE DIRECTION 1 & & -.070 & .050 & -34.6 \\
\hline \multirow[t]{2}{*}{6} & .921 & 0 . & FLOOR 6 COMPARTMENT & 1 & -.000 & 10.500 & -793.1 \\
\hline & & & OUTSIDE DIRECTION 1 & & -.081 & .050 & -37.0 \\
\hline \multirow[t]{2}{*}{7} & .786 & 0 . & FLOOR 7 COMPARTMENT & 1 & -.000 & 10.500 & -823.4 \\
\hline & & & OUTSIDE DIRECTION 1 & & -.091 & .050 & -39.4 \\
\hline \multirow[t]{2}{*}{8} & .651 & 9000 . & FLOOR 8 COMPARTMENT & 1 & -.001 & 10.500 & -873.8 \\
\hline & & & OUTSIDE DIRECTION 1 & & -.103 & .050 & -41.8 \\
\hline
\end{tabular}

THE FOLLOWING UNITS ARE USED FOR OUTPUT

FLOW IN CFM AT 70 DEG F AND 1 ATM

PRESSURE IN INCHS H2O

AREA IN FEET SQUARED 
ELEVATOR

TEMPERATURE PROFILE 1

SHAFT FLOW COEFFICIENT 140000.

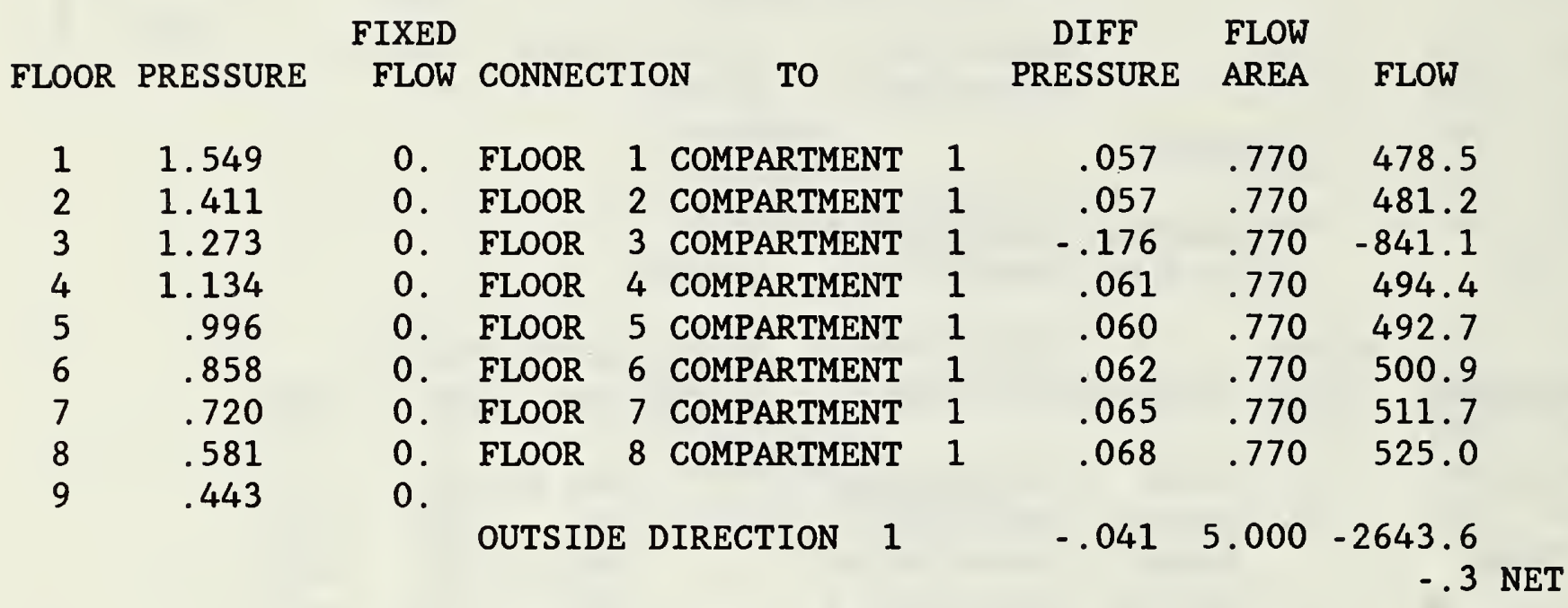

THE FOLLOWING UNITS ARE USED FOR OUTPUT

FLOW IN CFM AT 70 DEG F AND 1 ATM

PRESSURE IN INCHS H2O

AREA IN FEET SQUARED 
RUN 5 - PLAZA HOTEL - WITH ELEVATOR LOBBY

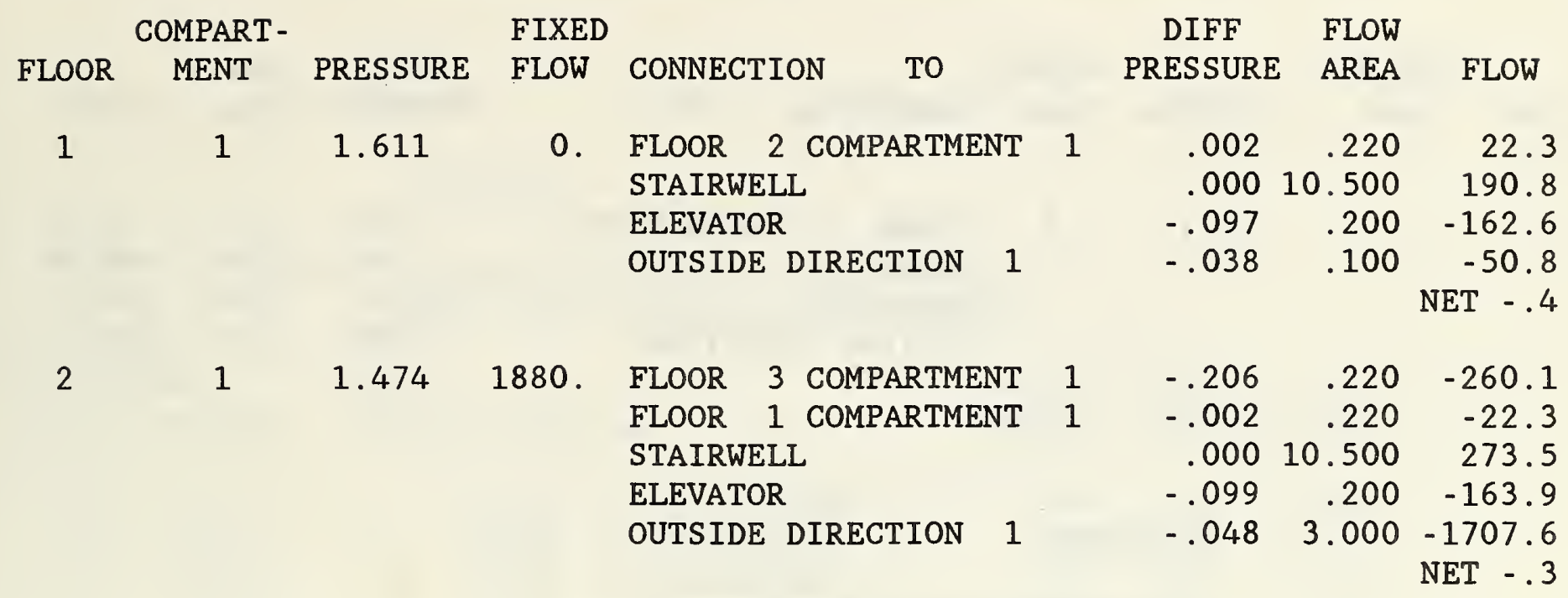

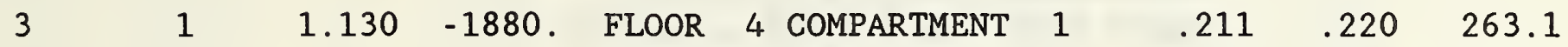
$\begin{array}{llllll}\text { FLOOR } & 2 \text { COMPARTMENT } & 1 & .206 & .220 & 260.1\end{array}$ $\begin{array}{llll}\text { STAIRWELL } & .208 & .290 & 344.4\end{array}$ $\begin{array}{llll}\text { ELEVATOR } & .107 & .200 & 170.5\end{array}$ $\begin{array}{lllll}\text { OUTSIDE DIRECTION } & 1 & .150 & .810 & 841.5\end{array}$ NET -.4

$\begin{array}{lllllllllll}4 & 1 & 1.202 & 1880 & \text { FLOOR } & 5 & \text { COMPARTMENT } & 1 & -.000 & .220 & -8.6\end{array}$ $\begin{array}{lllll}\text { FLOOR } 3 \text { COMPARTMENT } & 1 & -.211 & .220 & -263.1\end{array}$ STAIRWELL $\quad-.001 \quad 10.500 \quad-886.6$ $\begin{array}{llll}\text { ELEVATOR } & -.104 & .200 & -167.8\end{array}$ $\begin{array}{lllll}\text { OUTSIDE DIRECTION } & 1 & -.069 & .810 & -554.2\end{array}$ NET -.3

$\begin{array}{lllllllllll}5 & 1 & 1.064 & 0 . & \text { FLOOR } & 6 & \text { COMPARTMENT } & 1 & .002 & .220 & 24.7\end{array}$ $\begin{array}{llllll}\text { FLOOR } & 4 \\ \text { COMPARTMENT } & 1 & .000 & .220 & 8.6\end{array}$ $\begin{array}{llll}\text { STAIRWELL } & .000 & 10.500 & 719.3\end{array}$ $\begin{array}{llll}\text { ELEVATOR } & -.103 & .200 & -167.6\end{array}$ $\begin{array}{lllll}\text { OUTSIDE DIRECTION } & 1 & -.077 & .810 & -585.1\end{array}$ NET -.0

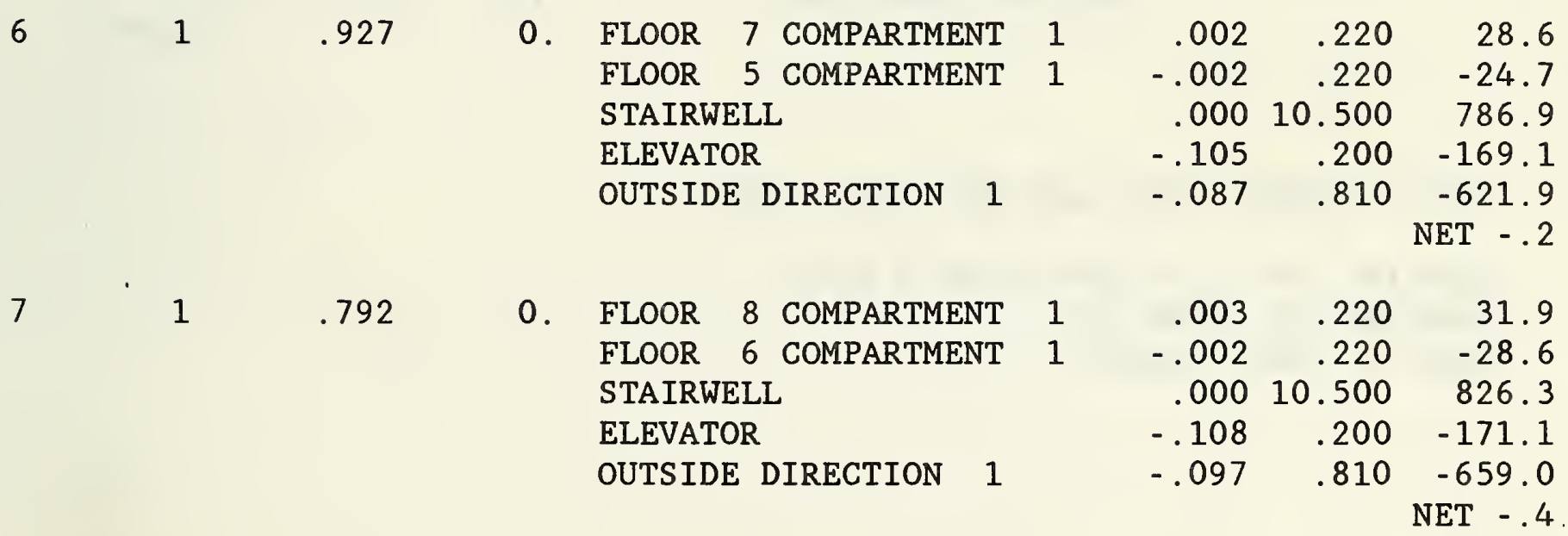




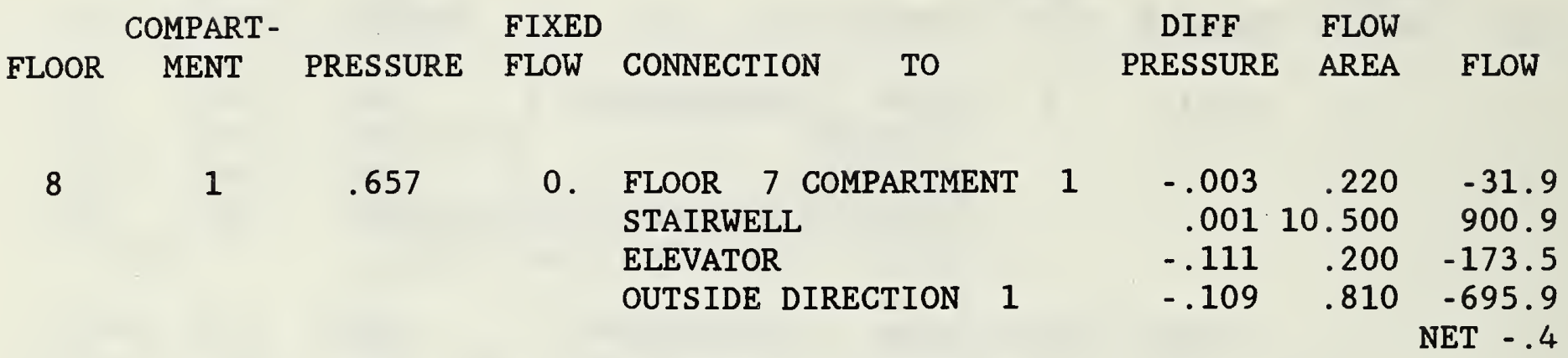

STAIRWELL

TEMPERATURE PROFILE 1 SHAFT FLOW COEFFICIENT 140000.

\begin{tabular}{|c|c|c|c|c|c|c|c|}
\hline OOR & PRESSURE & $\begin{array}{r}\text { FIXED } \\
\text { FLOW }\end{array}$ & CONNECTION & & $\begin{array}{c}\text { DIFF } \\
\text { PRESSURE }\end{array}$ & $\begin{array}{l}\text { FLOW } \\
\text { AREA }\end{array}$ & FLOW \\
\hline 1 & 1.611 & 0. & $\begin{array}{l}\text { FLOOR } 1 \text { COMPARTMENT } \\
\text { OUTSIDE DIRECTION }\end{array}$ & 1 & $\begin{array}{r}.000 \\
-.038\end{array}$ & $\begin{array}{l}10.500 \\
10.500\end{array}$ & $\begin{array}{r}-190.8 \\
-5339.2\end{array}$ \\
\hline 2 & 1.474 & 0 . & $\begin{array}{l}\text { FLOOR } 2 \text { COMPARTMENT } \\
\text { OUTSIDE DIRECTION }\end{array}$ & 1 & $\begin{array}{r}.000 \\
-.048\end{array}$ & $\begin{array}{r}10.500 \\
.100\end{array}$ & $\begin{array}{r}-273.5 \\
-57.0\end{array}$ \\
\hline 3 & 1.337 & 0. & $\begin{array}{l}\text { FLOOR } 3 \text { COMPARTMENT } \\
\text { OUTSIDE DIRECTION } 1\end{array}$ & 1 & $\begin{array}{l}-.208 \\
-.058\end{array}$ & $\begin{array}{l}.290 \\
.100\end{array}$ & $\begin{array}{r}-344.4 \\
-62.6\end{array}$ \\
\hline 4 & 1.201 & 0 . & $\begin{array}{l}\text { FLOOR } 4 \text { COMPARTMENT } \\
\text { OUTSIDE DIRECTION } 1\end{array}$ & 1 & $\begin{array}{r}.001 \\
-.068\end{array}$ & $\begin{array}{r}10.500 \\
.100\end{array}$ & $\begin{array}{l}886.6 \\
-67.9\end{array}$ \\
\hline 5 & 1.064 & 0. & $\begin{array}{l}\text { FLOOR } 5 \text { COMPARTMENT } \\
\text { OUTSIDE DIRECTION } 1\end{array}$ & 1 & $\begin{array}{l}-.000 \\
-.078\end{array}$ & $\begin{array}{r}10.500 \\
.100\end{array}$ & $\begin{array}{r}-719.3 \\
-72.6\end{array}$ \\
\hline 6 & .928 & 0 . & $\begin{array}{l}\text { FLOOR } 6 \text { COMPARTMENT } \\
\text { OUTSIDE DIRECTION } 1\end{array}$ & 1 & $\begin{array}{l}-.000 \\
-.088\end{array}$ & $\begin{array}{r}10.500 \\
.100\end{array}$ & $\begin{array}{r}-786.9 \\
-77.1\end{array}$ \\
\hline 7 & .793 & 0. & $\begin{array}{l}\text { FLOOR } 7 \text { COMPARTMENT } \\
\text { OUTSIDE DIRECTION }\end{array}$ & 1 & $\begin{array}{l}-.000 \\
-.098\end{array}$ & $\begin{array}{r}10.500 \\
100\end{array}$ & $\begin{array}{r}-826.3 \\
-81.7\end{array}$ \\
\hline 8 & .658 & 9000 . & $\begin{array}{l}\text { FLOOR } 8 \text { COMPARTMENT } \\
\text { OUTSIDE DIRECTION } 1\end{array}$ & 1 & $\begin{array}{l}-.001 \\
-.110\end{array}$ & $\begin{array}{r}10.500 \\
.100\end{array}$ & $\begin{array}{r}-900.9 \\
-86.3\end{array}$ \\
\hline
\end{tabular}

THE FOLLOWING UNITS ARE USED FOR OUTPUT

FLOW IN CFM AT 70 DEG F AND 1 ATM

PRESSURE IN INCHS H2O

AREA IN FEET SQUARED 
RUN 5 - PLAZA HOTEL - WITH ELEVATOR LOBBY

ELEVATOR

TEMPERATURE PROFILE 1

SHAFT FLOW COEFFICIENT 140000.

FIXED

FLOOR PRESSURE FLOW CONNECTION TO

$\begin{array}{ccc}\text { DIFF } & \text { FLOW } & \\ \text { PRESSURE } & \text { AREA } & \text { FLOW }\end{array}$

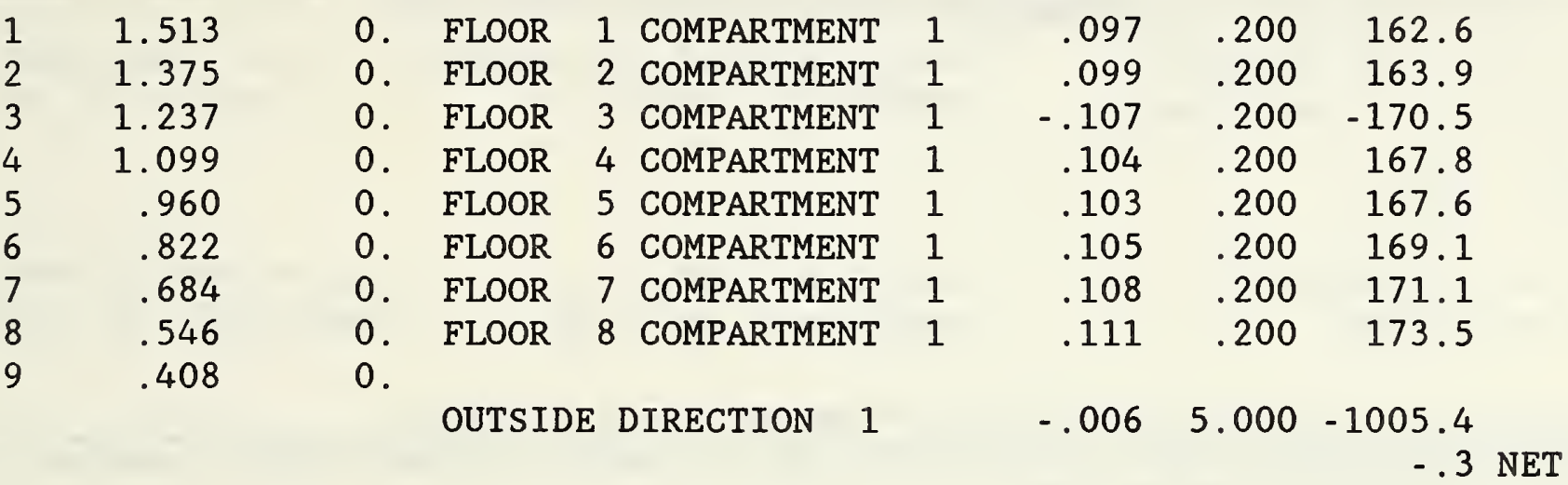

THE FOLLOWING UNITS ARE USED FOR OUTPUT

FLOW IN CFM AT 70 DEG F AND 1 ATM

PRESSURE IN INCHS H2O

AREA IN FEET SQUARED 
NBS. IIAA (REV. 2.80)

U.S. DEPT. OF COMM.

BIBLIOGRAPHIC DATA

SHEET (See in struction s)

1. PUBLICATION OR REPORT NO.

NBSIR-88/3800

2. Performing Organ. Report Noy 3. Publication Date

June 1988

4. TITLE AND SUBTITLE

Project Plan for Full Scale Smoke Movement and Smoke Control Tests

5. AUTHOR(S)

John H. Klote

6. PERFORMING ORGANIZATION (If jolnt or other than NBS, see in structions)

7. Contract/Grant No.

NATIONAL BUREAU OF STANDARDS

U.S. DEPARTMENT OF COMMERCE

GAITHERSBURG, MD 20899

9. SPONSORING ORGANIZATION NAME AND COMPLETE ADDRESS (Street, City, State, ZIP)

American Soclety of Heating,

Refrigerating, \& Conditioning

New Jersey Bell Telephone Co. Newark, NJ 07101

U.S. West Inc.

Engineers, Inc.

Atlanta GA 30329

Bell Atlantic Telephone Co.

Arlingt,on, VA 22201
U.S. Fire Admin.

Emmitsburg, MD 21727
U.S. Veterans Admin.

Washington, DC 20420

[Document describes a computer program; SF-185, FIPS Software Summary, is attached.

11. ABSTRACT (A 200-word or less foctual summary of most significant information. If document includes a signiflcant bibliography or literature survey, mention it here)

This report presents a project plan to test combinations of zoned smoke control and stairwell pressurization systems under real fire conditions to evaluate the appropriateness of current design methods of analysis for these systems. The report describes the test building, smoke control systems, calibration of building leakage areas, test instrumentation, and test series. As the project progresses much will be learned from the initial stages of work, and the need for some adjustments in the test series or other parts of the project plan may become apparent.

12. KEY WORDS (Six to twelve entries; alphabetical order; capitalize only proper names; and separate key words by semicolons) air movement; fire tests; pressurization; smoke control; stairwells

13. AVAILABILITY

Q Unlimited

$\square$ For Official Distribution. Do Not Release to NTIS

$\square$ Order From Superintendent of Documents, U.S. Government Printing Office, Washington, D.C. 20402.

14. NO. OF PRINTED PAGES

51

15. Price

$\$ 13.95$

[X] Order From National Technical Information Service (NTIS), Springfield, VA. 22161 

